\title{
Predicting Long-Term Moisture Contents of Earthen Covers at Uranium Mill Tailings Sites
}
G. W. Gee
K. K. Nielson
V. C. Rogers

September 1984

Prepared for the U.S. Department of Energy under Contract DE-AC06-76RLO 1830

Pacific Northwest Laboratory Operated for the U.S. Department of Energy by Battelle Memorial Institute 


\title{
DISCLAIMER
}

This report was prepared as an account of work sponsored by an agency of the United States Government. Neither the United States Government nor any agency thereof, nor any of their employees, makes any warranty, express or implied, or assumes any legal liability or responsibility for the accuracy, completeness, or usefulness of any information, apparatus, product, or process disclosed, or represents that its use would not infringe privately owned rights. Reference herein to any specific commercial product, process, or service by trade name, trademark, manufacturer, or otherwise, does not necessarily constitute or imply its endorsement, recommendation, or favoring by the United States Government or any agency thereof. The views and opinions of authors expressed herein do not necessarily state or reflect those of the United States Government or any agency thereof.

\author{
PACIFIC NORTHWEST LABORATORY \\ operated by \\ BATTELLE \\ for the \\ UNITED STATES DEPARTMENT OF ENERGY \\ under Contract DE-AC06-76RLO 1830
}

\begin{tabular}{|c|c|}
\hline \multicolumn{2}{|c|}{ Printed in the United States of America } \\
\hline \multicolumn{2}{|c|}{$\begin{array}{c}\text { Available from } \\
\text { National Technical Information Service }\end{array}$} \\
\hline \multicolumn{2}{|c|}{ National Technical Information Service } \\
\hline \multicolumn{2}{|c|}{5285 Port Royal Road } \\
\hline \multicolumn{2}{|c|}{ Springfield, Virginia 22161} \\
\hline \multirow{2}{*}{\multicolumn{2}{|c|}{$\begin{array}{l}\text { NTIS Price Codes } \\
\text { Microfiche } A 01\end{array}$}} \\
\hline & \\
\hline \multicolumn{2}{|c|}{ Printed Copy } \\
\hline & Price \\
\hline Pages & Codes \\
\hline $001-025$ & $\mathrm{~A} 02$ \\
\hline $026-050$ & A03 \\
\hline 051-075 & A04 \\
\hline $076-100$ & A05 \\
\hline $101-125$ & A06 \\
\hline $126-150$ & A07 \\
\hline $151-175$ & $\mathrm{~A} 0 \mathrm{~B}$ \\
\hline $176-200$ & $\mathrm{~A} 09$ \\
\hline $201-225$ & A010 \\
\hline $226-250$ & A011 \\
\hline $251-275$ & A012 \\
\hline $276-300$ & A013 \\
\hline
\end{tabular}


PREOICTING LONG-TERM MOISTURE CONTENTS OF EARTHEN COVERS AT URANIUM MILL

TAILINGS SITES
G. W. Gee
K. K. Nielson*
V. C. Rogers*

September 1984

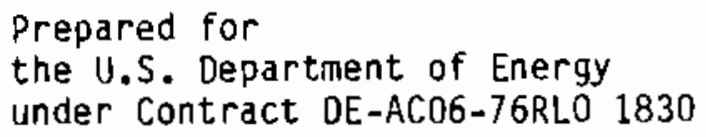

Pacific Northwest Laboratory

Richland, Washington 99352

\footnotetext{
* Nielson and Rogers are with Rogers and Associates Engineering Corp., Salt Lake City, Utah.
} 
$-$

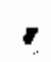

-

. 


\section{ACKNOWLEDGMENTS}

The research described in this report has been a team effort by two groups, Pacific Northwest Laboratory (PNL), and Rogers and Associates Engineering (RAE). Special appreciation is expressed to P. R. Heller (PNL) for soil characterization and hydraulic property measurements and to Bryan Bowser (RAE) for the radon diffusion measurements on the compacted soil materials. We also thank Jacobs Engineering Corporation, Technical Assistance Contractor for the Uranium Mill Tailings Remedial Action Project (UMTRAP), for their interest during the course of this study. 
r

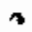




\section{EXECUTIVE SUMMARY}

The release of radon gas from uranium mill tailings is considered a potential health hazard and must be controlled. One method of containing these radioactive materiais is to cover the tailings piles. Pacific Northwest Laboratory (PNL) and Rogers and Associates Engineering (RAE) under contract to the U.S. Department of Energy's Uranium Mill Tailings Remedial Action Project (UMTRAP) office have investigated the use of earthen covers for radon barrier systems at uranium mill tailings sites. Thick $(3 \mathrm{~m})$ earthen covers were tested as part of an extensive field test of engineered covers at Grand Junction, Colorado (Hartley et al. 1983). After 3 years these tests have shown that when soil covers are wetted and compacted they can be successful in controlling radon flux to levels below Environmental Protection Agency (EPA) background limits (<20 pCi $\left.\mathrm{m}^{-2} \mathrm{~s}^{-1}\right)$.

What remains unknown is the long-term effectiveness of these and other earthen cover systems in controlling radon. Assuming that the cover is physically stable and is not affected by wind or water erosion, it is the longterm (residual) moisture content that will determine the effectiveness of an earthen cover in controlling radon gas exhalation. The objectives of this study were to determine the effects of moisture and soil compaction on radon diffusion for pit-run soil materials used in earthen cover designs, and to evaluate three methods for predicting long-term moisture content of earthen covers. The three methods for long-term moisture prediction covered in this report are 1) estimates from water retention (permanent wilting point) data, 2) correlation with climate and soil type, and 3) detailed model simulation.

The results of our testing have shown the following:

- Soils vary greatly in residual moisture. Expected long-term moisture saturation ratios (based on generalized soil characteristics) range from 0.2 to 0.8 for soils ranging in texture from sand to clay, respectively. These values hold for noncompacted field soils.

- Measured radon diffusion coefficients for soils at 15-bar water contents ranged from $5.0 \mathrm{E}-2 \mathrm{~cm}^{2} / \mathrm{s}$ to $5.0 \mathrm{E}-3 \mathrm{~cm}^{2} / \mathrm{s}$ for sands and clays, respectively, at typical field densities. 
- In contrast, fine-textured pit-run earthen materiais, subjected to optimum compaction (>85\% Proctor density) and dried to the 15-bar water content, ranged from 0.7 to 0.9 moisture saturation. Compacted pit-run soils at these moisture contents exhibited radon diffusion coefficients as low as $3.0 \mathrm{E}-4 \mathrm{~cm}^{2} / \mathrm{s}$.

- The residual moisture saturation for cover soils is not known since no engineered barrier has been in place for more than a few years.

- A comparison of methods for predicting moisture saturation indicates that model simulations are useful for predicting effects of climatic changes (increased or decreased precipitation) on residual soil moisture, but that long-term moisture also can be predicted with some degree of confidence using generalized soil properties or empirical correlations based both on soils and climatic information.

- The optimal sojl cover design will likely include more than one layer of soil (a multilayer design). A two-layer system using a thick (1-m minimum) plant root zone of uncompacted soil placed over a moistened, tightly compacted fine-textured soil is recommended. This design concept has been tested successfully at the Grand Junction, Colorado, tailings pites. 


\section{CONTENTS}

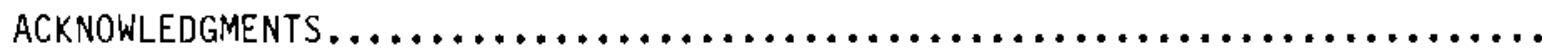

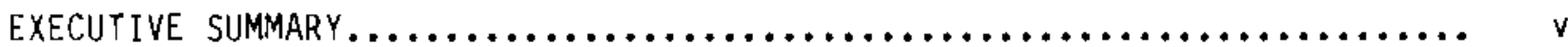

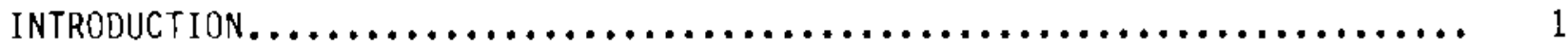

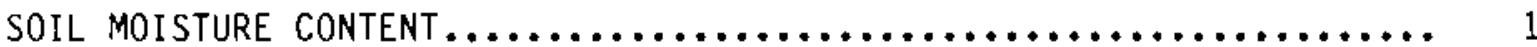

COVER THICKNESS.................................... 2

COVER DESIGN CALCULATIONS............................ 2

CLIMATIC FACTORS $\ldots \ldots \ldots \ldots \ldots \ldots \ldots \ldots \ldots \ldots \ldots \ldots \ldots \ldots \ldots \ldots \ldots \ldots \ldots \ldots$

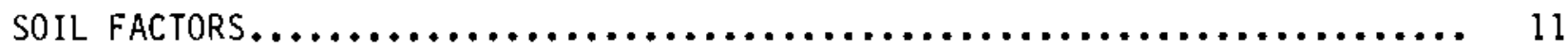

SOIL MOISTURE AND RADON DIFFUSION TESTS FOR PIT-RUN SOILS $\ldots \ldots \ldots \ldots . .11$

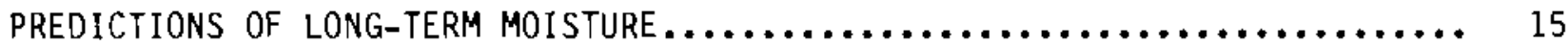

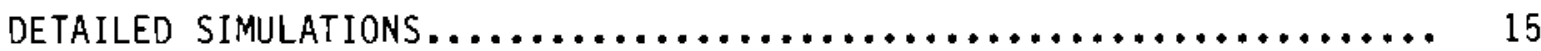

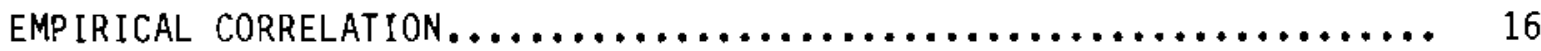

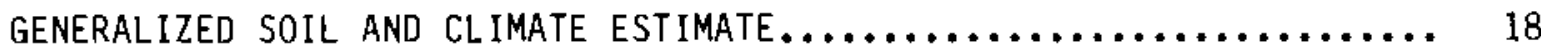

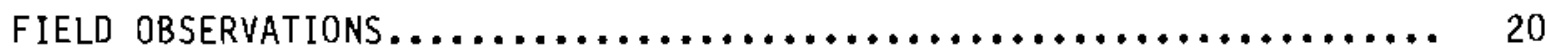

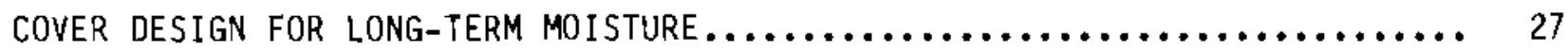

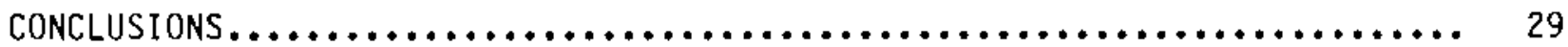

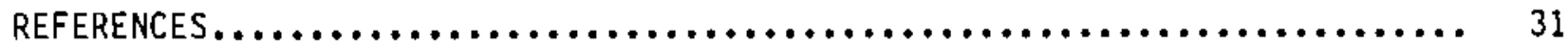

APPENDIX A - SOIL MOISTURE, DENSITY, POROSITY, AND RADON

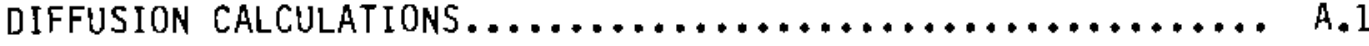




\section{FIGURES}

1. Effect of Moisture Saturation on Earthen Cover Thickness............ 4

2. Location of Inactive Uranium Mill Tailings Piles.................. 8

3. Moisture Content Changes in Soil with Time at a Grassland site in Colorado............................................. 10

4. Radon Diffusion Coefficients as a Function of Moisture Saturation for Pit-Run Soil Materials Compacted to $>85 \%$ Proctor Density and Equilibrated at 15-Bar Water Content.......................... 13

5. Simulated Water Content Profiles for a Multilayered Earthen Cover After 4 and 5 Years of Dry Climatic Conditions at Grand Junction, Colorado.................................... 17

6. Changes in Moisture Saturation Leve1s with Time in Soil at Selected Depths Below Shelterbelt Trees Near Mandan,

7. Moisture Saturation for 24-Month Periods for Surface Soils at Arid and Semiarid Sites where Data are Available from the Literature................................................ 24

A.1 Relationship Between Dry Weight, $M_{d}$, and Wet Weight, $M_{w}$ Moisture Percentage, and Moisture Saturation, $m$, for Two Soils....... A.3

A.2 Calculated Cover Thickness as a Function of Dry Bulk Density at Two Soil Moistures........................................ A.4 


\section{TABLES}

1. Radon Diffusion Coefficients for Selected Earthen Cover Materials Compacted to Various Proctor Densities and Equilibrium at 15 Bar Water Content....................................... 12

2. IMTRAP Sites and Expected Long-Term Saturation Levels Based on Generalized Soils and Climate Data......................... 20

3. Moisture Saturation at 15-Bar Water Content for 20 Soil Samples Taken Adjacent to UMTRAP Sites............................. 21

4. Average Moisture Saturation in Meters in the Top $0.3 \mathrm{~m}$ of Earthen Cover Materials Overlying Four Uranium Mill Tailings Piles Compared to 15 Bar Measurenent and Climate/Moisture Correlation...... 25

A.1 Physical Relationships of Earthen Cover Materials................ A.3 


\section{INTRODUCTION}

Radon gas release from uranium mill tailings is considered a potential radiation health hazard if inhaled by persons near the tailings site. The potential health effects relate to breathing air containing radon decay products with short half-lives, such as polonium-218, and exposing the lungs and other internal organs to alpha radiation. Because of this potential health hazard and the fact the radon will continue to be produced from the radium and thorium present in the tailings, the Environmental Protection Agency (EPA) (EPA 1983) has established strict standards for disposal of these tailings. The EPA standards limit the annual average rate of radon gas, released to the

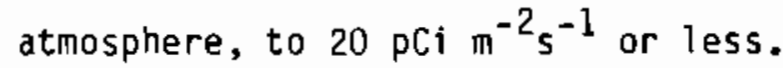

Pacific Northwest Laboratory (PNL) and Rogers and Associates Engineering (RAE) under contract to the U.S. Department of Energy's Uranium Mill Tailings Remedial Action Project (UMTRAP) have investigated the role of soil moisture in maintaining a barrier to radon diffusion. Predicting moisture content over the long-term will help to design and evaluate cover systems.

Earthen covers for uranium mill tailings sites are composed of geologic materials (soils, sediments), that are engineered to create a diffusion barrier that delays the escape of radon $(R n-222)$ gas to the atmosphere. The cover system is designed to impede the transport process until radon decays to acceptable levels. Thickness, moisture content, and compaction are three properties that can be designed into a cover system to limit radon diffusion to the atmosphere. An example of a successful earthen cover design exists at the Grand Junction, Colorado, inactive tailings pile. At this site an area with an initial surface radon flux of $600 \mathrm{pCi} \mathrm{m} \mathrm{m}^{-2} \mathrm{~s}^{-1}$ was covered with a $3-m$ thick earthen cover system containing wetted, compacted shale. This covered area has maintained a surface radon $f l u x$ below $2 \mathrm{pCi} \mathrm{m} \mathrm{m}^{-2} \mathrm{~s}^{-1}$ for the past 3 years (Hartley et al. 1983).

\section{SOIL MOISTURE CONTENT}

Moisture content is the major soil property controlling radon diffusion through earthen cover systems. Soil moisture content can be expressed in 
several ways. Appendix A details functional relationships between moisture content, density, and porosity. For purposes of this report, we express water content as a saturation ratio, $m$, which is the ratio of water actually present in soil to the total porosity (that which would be present if all the pores were water-filled). Typical soil saturation ratios range from less than 0.2 for coarse sands at climatically dry sites to more than 0.8 for clays at wet sites. Major concerns in designing earthen covers relate to accurately predicting long-term soil moisture content in the cover and thereby providing "reasonable assurance" that the cover will perform adequately as a radon barrier for extended time (up to 1000 years).

\section{COVER THICKNESS}

Cover thickness requirements at uranium mill tailings sites can be calculated using a gas diffusion model that accounts for radon decay (3.8-day halflife), the initial radon flux, and the moisture and compaction dependence of the radon diffusion coefficient, $D$. Details of these calculations are given in the following section and also provided in recent reports by Mayer et al. (1981) and Rogers, Nielson and Kalkwarf (1984). For example, a single-layer soil cover at an arid site must be $4.6 \mathrm{~m}(15 \mathrm{ft})$ to meet the $<20 \mathrm{pCi} \mathrm{m} \mathrm{m}^{-2} \mathrm{~s}^{-1}$ radon flux limit (EPA 1983) if the soil is coarse and dry (D=0.05 cm/s) and the initial radon flux is $400 \mathrm{pCi} \mathrm{m} \mathrm{m}^{-2} \mathrm{~s}^{-1}$. In contrast, a cover thickness of less than $1.5 \mathrm{~m}(5 \mathrm{ft})$ is required at the same site if the soil is compacted and can retain water so that the cover diffusion coefficient, $D$, is reduced to less than $0.005 \mathrm{~cm} / \mathrm{s}$. The dependence of cover thickness on moisture content and density cannot be overemphasized. Significant cost savings in materials may be realized if cover materials can be found or engineered to have low diffusion coefficients. This means that efforts should be expended to select materials that compact well and retain moisture for long periods of time.

\section{COVER DESIGN CALCULATIONS}

Radon diffusion measurements have been correlated with moisture contents, and a predictive correlation between the radon diffusion coefficient, $D$, and the moisture saturation, $m$, has been developed using a wide range of soil 
materials at various moisture contents and compaction densities (Rogers et al. 1982a). The relationship can be expressed as

$$
D=0.07 \exp \left[-4 m\left(1-p+m^{4}\right)\right]
$$

where $D$ is the radon diffusion coefficient in $\mathrm{cm}^{2} / \mathrm{s}$,

$m$ is the moisture saturation ratio, and

$P$ is the porosity of the soil in $\mathrm{cm}^{3} / \mathrm{cm}^{3}$.

The correlation expressed above (Equation 1) is based on over 100 measurements and has a geometrical standard deviation (GSD) of about 2.0. Using diffusion theory, Rogers et al. (1982b) and Rogers, Nielson and Kalkwarf (1984) have shown that earthen cover thickness can be caiculated if the radon diffusion coefficient and the porosity of the cover and tailings are known. For applications where the tailings are thicker than $1 \mathrm{~m}$, the value of a single-layer cover thickness can be obtained using the relationship,

$$
x_{c}=0_{c} / \lambda \ln \frac{2 J_{t} / J_{c}}{1+a_{t} / a_{c}+\left(1-a_{t} / a_{c}\right)\left(J_{c} / J_{t}\right)^{2}}
$$

where $x_{C}=$ cover thickness

$$
\begin{aligned}
a_{t}= & P_{t} 0_{t}\left(1-0.74 m_{t}\right)^{2} \\
a_{c}= & P_{c}^{2} D_{c}\left(1-0.74 m_{c}\right)^{2} \\
J_{t}= & \text { Bare tailings radon flux } \\
J_{c}= & \text { Radon flux control limit (e.9., } \left.20 \mathrm{pCi} \mathrm{m}^{-2} \mathrm{~s}^{-1}\right) \\
\lambda= & \text { radon decay constant }=2.1 \mathrm{E}-06 \mathrm{~s}^{-1} \\
P_{i}= & \text { porosity }(i=c \text { or } t) \\
D_{i}= & \text { bulk diffusion coefficient }(i=c \text { or } t ; i . e ., \text { cover or } \\
& \text { tailings) } \\
m_{i}= & \text { moisture saturation ratio. }
\end{aligned}
$$

For typical applications at sites where bare surface flux exceeds $100 \mathrm{pCi}$ $\mathrm{m}^{-2} \mathrm{~s}^{-1}$ and the desired control limit is $20 \mathrm{pCi} \mathrm{m} \mathrm{m}^{-2}$ or less, the third term in the denominator of the logarithm can be neglected. For multiple layers of 
cover, detailed computer codes also are available for computing the surface radon flux for earthen covers with multiple layers.

By using Equation (2), we can calculate the dramatic effect of moisture saturation on required cover thickness (Figure 1). The calculations assume a radon diffusion coefficient of $8.0 \mathrm{E}-03 \mathrm{~cm}^{2} / 5$ for tailings and a porosity of 0.4 . A typical bare surface radon flux of $300 \mathrm{pCi} \mathrm{m}^{-2} \mathrm{~s}-1$ will require a single-layer cover thickness ranging from less than $1 \mathrm{~m}$ to more than $4 \mathrm{~m}$ as moisture saturation ranges from 0.7 to 0.1 . It is apparent that a wet cover system is highly desirable. For this system, the required cover thickness nearly doubles $(1.7$ to $3.2 \mathrm{~m}$ ) as moisture saturation is reduced from 0.5 to 0.3 .

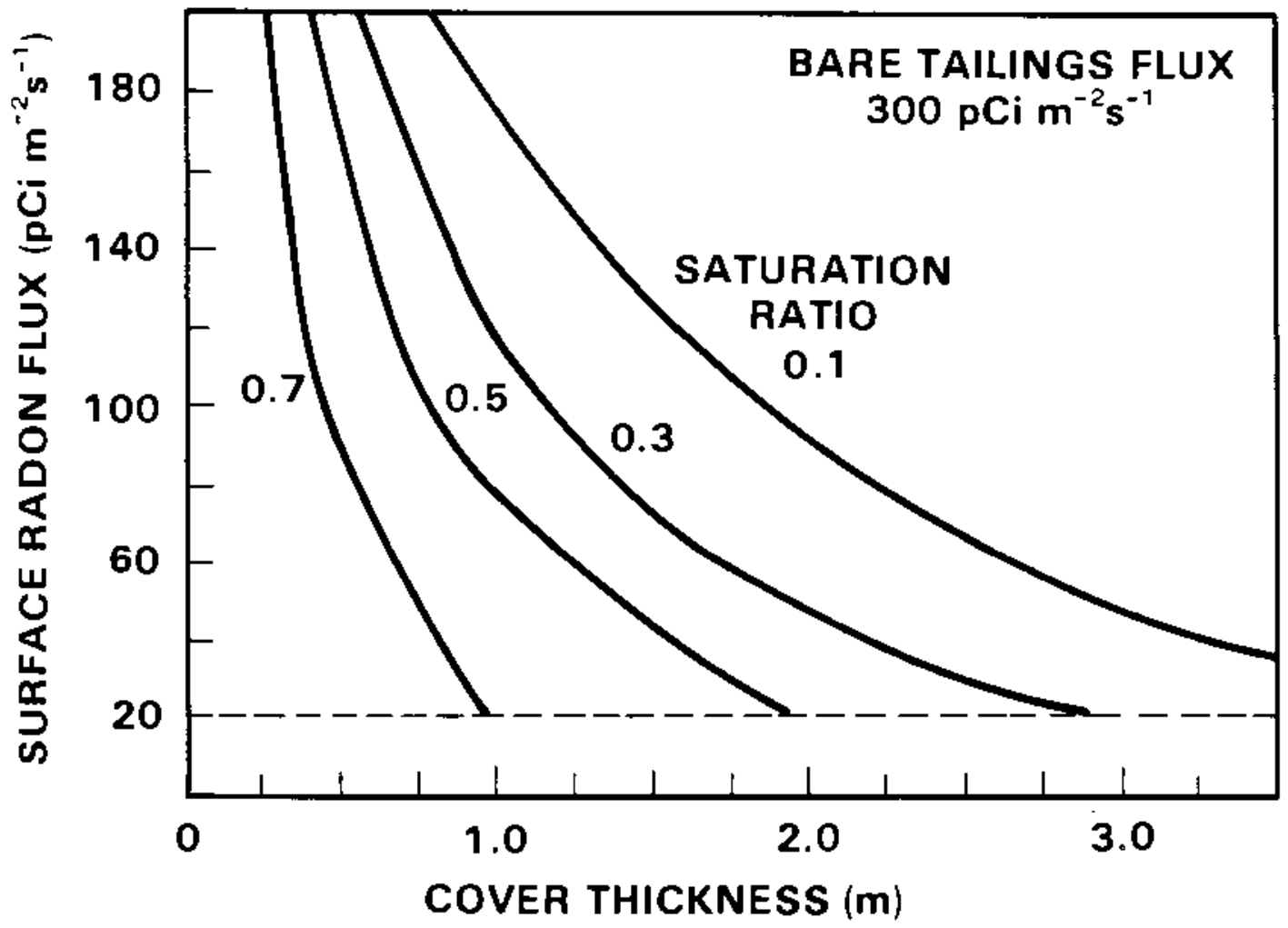

FIGURE 1. Effect of Moisture Saturation on Earthen Cover Thickness 
Because cover moisture is a transient, it is important to study moisture control mechanisms. To evaluate both the impact of moisture changes and effects of long-term residual moisture on radon diffusion, it is necessary to consider the two major factors controlling moisture content in soils, namely 1) climatic moisture controls and 2) soit property controls. 
+ . 


\section{CLIMATIC FACTORS}

Seasonal variations in soil moisture content caused by climatic factors (precipitation, evaporation and plant transpiration) play a major role in determining expected long-term cover water contents.

All but two of the Uranium Mill Tailings Remedial Action Program (UMTRAP) sites (see Figure 2) (Canonsburg, Pennsylvania, and Falls City, Texas) can be grouped into three general regions based on climate and geography: the Colorado Plateau, the West Slope of the Rocky Mountains, and the Northern Great Plains. The Canonsburg and Falls City sites are located in humid areas with rainfall exceeding $100 \mathrm{~cm} / \mathrm{yr}$. The wet site conditions are so drastically different from the other UMTRAP sites that soil moisture predictions at Canonsburg and Falls city should be considered separately. In general, these sites have soil moisture saturation ratios that exceed 0.6 for most of the year and conditions of complete saturation $(m=1.0)$ will likely occur during winter months.

The Colorado Plateau sites (Grand Junction, Green River, Tuba City, Shiprock, Monument Valley, Mexican Hat, Slick Rock, and Ambrosia Lake), have annual precipitation ranging from $15 \mathrm{~cm}$ at Monument Valley, Arizona, and Shiprock, New Mexico, to $28 \mathrm{~cm}$ at Slick Rock, Colorado. Frequency of rain events vary considerably at these sites, but summers are hot and precipitation is sufficiently low that plant cover is relatively sparce with water being the major limiting factor for growth. It is expected that soils in these regions are dried to the plant wilting point throughout the root zone during much of the year and that conservative estimates of average water contents could be made by determining the soil water contents at plant wilting, typically estimated by a laboratory measurement of the water retained in soil at an applied pressure of 15 bars using a standard pressure plate apparatus (Richards 1965).

The West Slope sites (Gunnison, Durango, Rifle, Naturita, Maybell, Salt Lake, Lakeview, and Lownan) generally have moderate precipitation ranging from $28 \mathrm{~cm}$ at Gunnison and Rifle to $57 \mathrm{~cm}$ at Lownan. No general conclusions can be made about the climate at these sites except that evaporation conditions are 


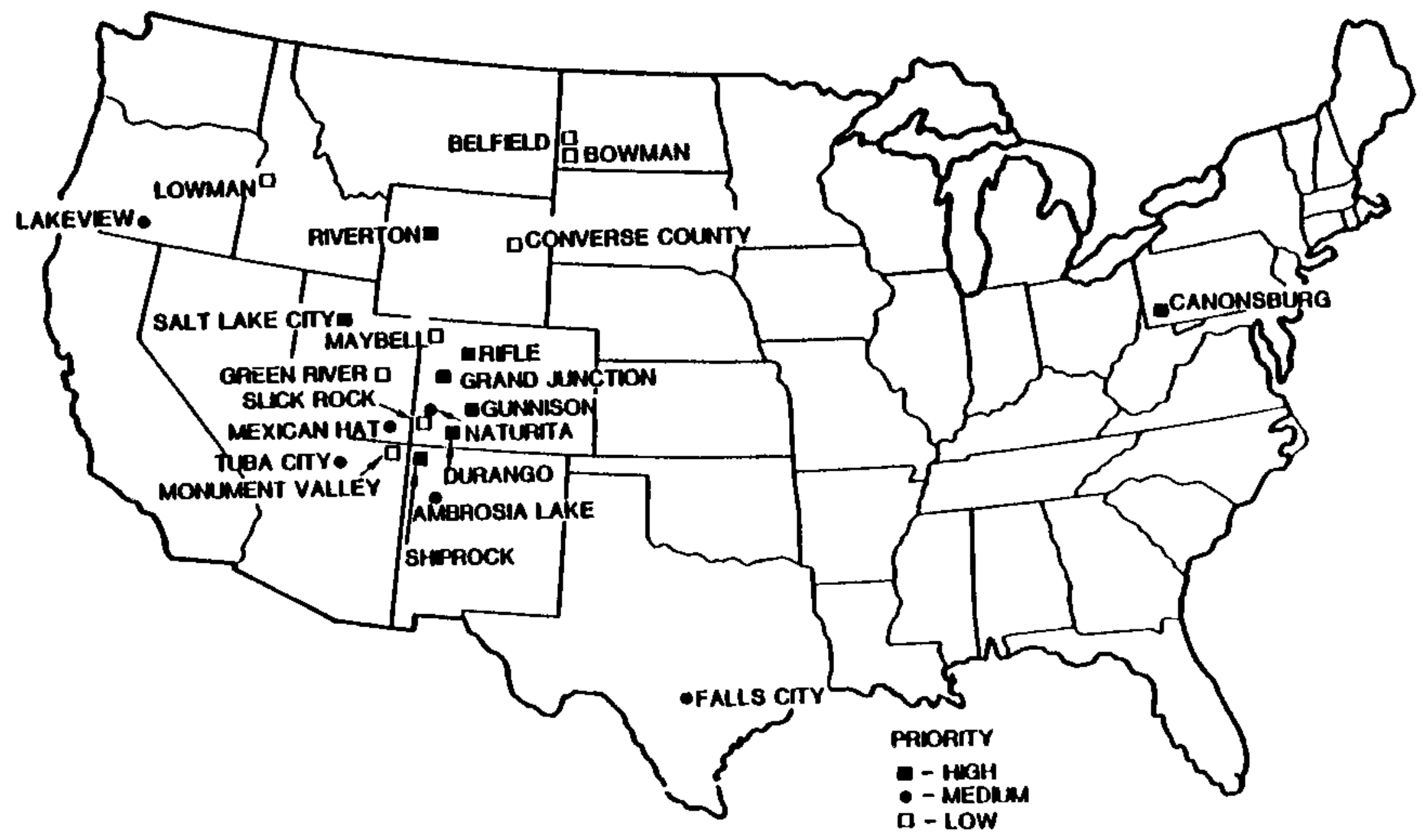

FIGURE 2. Location of Inactive Uranium Mill Tailings Piles. Priority for Remedial Action is identified by coded symbols. 
sufficiently severe at most of these sites so that plant water removal depletes the root zone to wilting conditions at least during the summer months. The water contents at these sites are expected to range between a field capacity and wilting point that can be estimated to lie between the water contents held at 0.3 and 15 bars determined by pressure plate measurements in the laboratory.

Similar general statements can be made for the Northern Great Plains sites (Riverton, Converse County, Bowman, and Belfield). It is anticipated that most available cover materials will contain sufficient clay so that the water contents held at 0.3 bars would approximate the upper 1 imit of stored water and the lower limit would be estimated from the water held at 15 bars. Average annual moisture content for a soil cover at these sites would be expected to be greater than that found at the 15 bars water content.

A single set of observations of moisture content in a cover for a given time provides only a very limited basis for determining the long-term moisture content that will ultimately control radon diffusion. Moisture content in cover soils vary in time; hence, a comprehensive analysis requires extensive repeated sets of measurements of water content over a rather lengthy period of time (years). Examples of moisture changes with time in a soil profile are shown in

Figure 3 for a grassland site in Colorado (Galbraith 1971). Note that most of the fluctuations in moisture occurred in this sandy soil in the top $1 \mathrm{~m}$ and the lower depths remained near the wilting point moisture throughout the test period. 


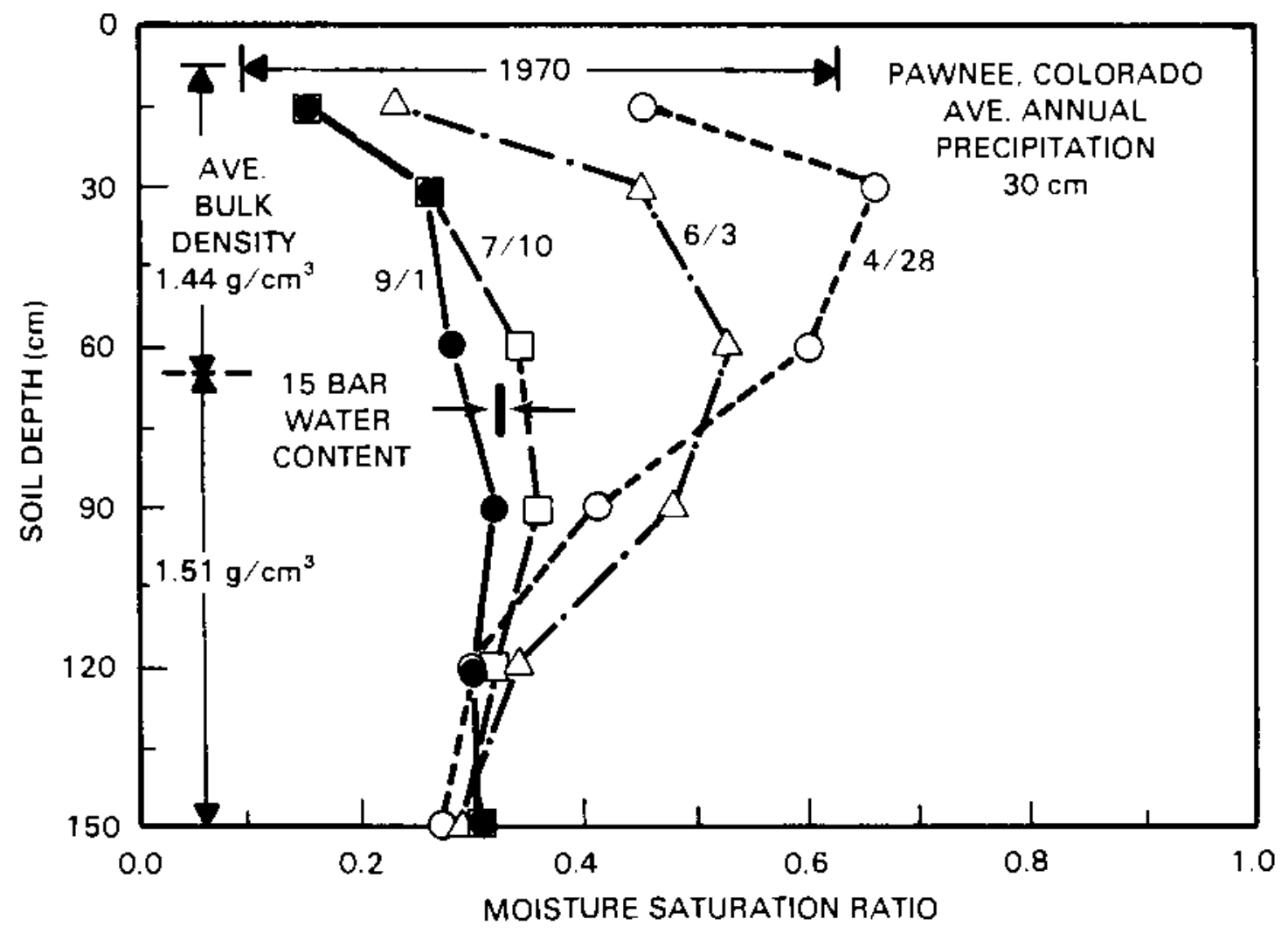

FIgURE 3. Moisture Content Changes in Soil with Time at a Grassland Site in Colorado (after Galbraith 1971) 


\section{SOIL FACTORS}

In addition to moisture content, radon diffusion is affected by the soil bulk density and soil compaction. We have measured radon diffusion coefficients for candidate earthen cover samples and found that radon flux can be reduced significantly and the required cover thickness decreased when compacted soil is used for a radon cover system. For a compacted soil, the moisture saturation tends to increase as compaction increases (1ess air space). The reduced radon flux is attributed largely to the increased moisture saturation which in turn increased the water retention capabilities of compacted soils.

\section{SOIL MOISTURE AND RADON DIFFUSION TESTS FOR PIT-RUN SOILS}

Soils used in earthen covers at a given site will be taken from local borrow pits. Often these pit-run materials will contain mixtures of fine soils, sand, gravel, and rock and be rather heterogeneous. Screening of large materials may be required. If shale materials are used, large aggregates may need to be crushed to facilitate uniform spreading on the cover. These kinds of materials have somewhat different characteristics than typical surface soils. In field tests at Grand Junction, Gee et al. (1981) used materials consisting of gravels mixed with clays which were tested and found to have some unique properties, namely high density and low air-filled porosity (high moisture saturation ratios). Although these materials were used successfully as the key component of a 'multilayer' earth barrier, the material handing costs were unreasonably high (Hartley et al. 1983). Pit-run materials have somewhat similar features in that wide ranges in particle size are often obtained in pits where gravel, sands, and silts are mixed together. We tested a number of borrow-pit materials taken from areas near mill tailings sites to determine their compaction, moisture, and radon diffusion characteristics. Based on our assumption that a reasonable estimate of residual moisture in these materials would be the permanent wilting point (15-bar water content), we compacted the pit-run materials, after conditioning them at a moisture content that was near or equal the 15-bar moisture content. This moisture content was determined by a laboratory measurement using a pressure plate apparatus 
(Richards 1965). The radon diffusion measurements were made using the transient, short-column method described by Nielson et al. (1981).

Table 1 lists moisture content and calculated and measured diffusion coefficient results from five pit-run test materials at several compactions. Figure 4 shows these data in relationship to Equation (1). Computed radon diffusion coefficients were within a factor of three of the measured values. The average ratio of measured to computed diffusion coefficient was 1.2. The results suggest that pit-run materials yield diffusion coefficient values similar to uniform, nonstony soils. The data further suggest that the empirical relationship relating radon diffusion to moisture saturation holds for most soils and earthen materials that would be available for use at UMTRAP sites. The data suggest that compaction significantly increases the moisture saturation range and concurrently produces a range of lower radon diffusion coefficients than those found in uncompacted native soils.

TABLE 1. Radon Diffusion Coefficients for Selected Earthen Cover Materials Compacted to Various Proctor Densities (ASTM-1557D) and Equilibrium at 15 Bar Water Contents

\begin{tabular}{|c|c|c|c|c|c|c|}
\hline \multirow[t]{3}{*}{ Sample } & \multirow{3}{*}{$\begin{array}{c}\text { Bulk } \\
\text { Density } \\
\left(\mathrm{g} / \mathrm{cm}^{3}\right)\end{array}$} & \multirow{3}{*}{$\begin{array}{l}\% \text { Proctor } \\
\text { Density } \\
-\infty\end{array}$} & \multirow{3}{*}{$\frac{\begin{array}{c}\text { Water } \\
\text { Content }\end{array}}{\text { (dry wt } \%)}$} & \multirow{3}{*}{$\begin{array}{c}\text { Moisture } \\
\text { Saturation }\end{array}$} & \multirow{2}{*}{\multicolumn{2}{|c|}{$\frac{\begin{array}{c}\text { Radon Diffusion } \\
\text { Coefficient }\end{array}}{\left(\mathrm{cm}^{2} / \mathrm{s}\right)}$}} \\
\hline & & & & & & \\
\hline & & & & & Measured & Computed \\
\hline Durango-shale & $\begin{array}{l}1.88 \\
1.73\end{array}$ & $\begin{array}{l}95 \\
87\end{array}$ & $\begin{array}{l}12.4 \\
10.7\end{array}$ & $\begin{array}{l}0.77 \\
0.52\end{array}$ & $\begin{array}{l}9.3 E-4 \\
6.2 E-3\end{array}$ & $\begin{array}{l}1.4 E-3 \\
9.8 E-3\end{array}$ \\
\hline Salt Lake-pit & $\begin{array}{l}1.92 \\
1.86\end{array}$ & $\begin{array}{l}91 \\
89\end{array}$ & $\begin{array}{l}5.3 \\
4.0\end{array}$ & $\begin{array}{l}0.35 \\
0.24\end{array}$ & $\begin{array}{l}3.2 \mathrm{E}-2 \\
4.1 \mathrm{E}-2\end{array}$ & $\begin{array}{l}1.9 E-2 \\
2.9 E-2\end{array}$ \\
\hline Grand Jct-pit & $\begin{array}{l}2.00 \\
1.88\end{array}$ & $\begin{array}{l}97 \\
91\end{array}$ & $\begin{array}{l}6.5 \\
9.3\end{array}$ & $\begin{array}{l}0.50 \\
0.57\end{array}$ & $\begin{array}{l}2.6 E-2 \\
5.0 E-3\end{array}$ & $\begin{array}{l}9.6 \mathrm{E}-3 \\
6.9 \mathrm{E}-3\end{array}$ \\
\hline Grand Jct-adobe & $\begin{array}{l}1.88 \\
1.84\end{array}$ & $\begin{array}{l}91 \\
89\end{array}$ & $\begin{array}{l}11.1 \\
14.4\end{array}$ & $\begin{array}{l}0.69 \\
0.83\end{array}$ & $\begin{array}{l}1.4 E-3 \\
4.0 E-4\end{array}$ & $\begin{array}{l}3.1 E-3 \\
7.4 E-4\end{array}$ \\
\hline Grand Jct-shale & $\begin{array}{l}1.89 \\
1.79\end{array}$ & $\begin{array}{l}95 \\
90\end{array}$ & $\begin{array}{l}15.0 \\
15.7\end{array}$ & $\begin{array}{l}0.95 \\
0.83\end{array}$ & $\begin{array}{l}2.8 E-4 \\
3.0 E-4\end{array}$ & $\begin{array}{l}1.0 E-4 \\
7.6 E-4\end{array}$ \\
\hline
\end{tabular}




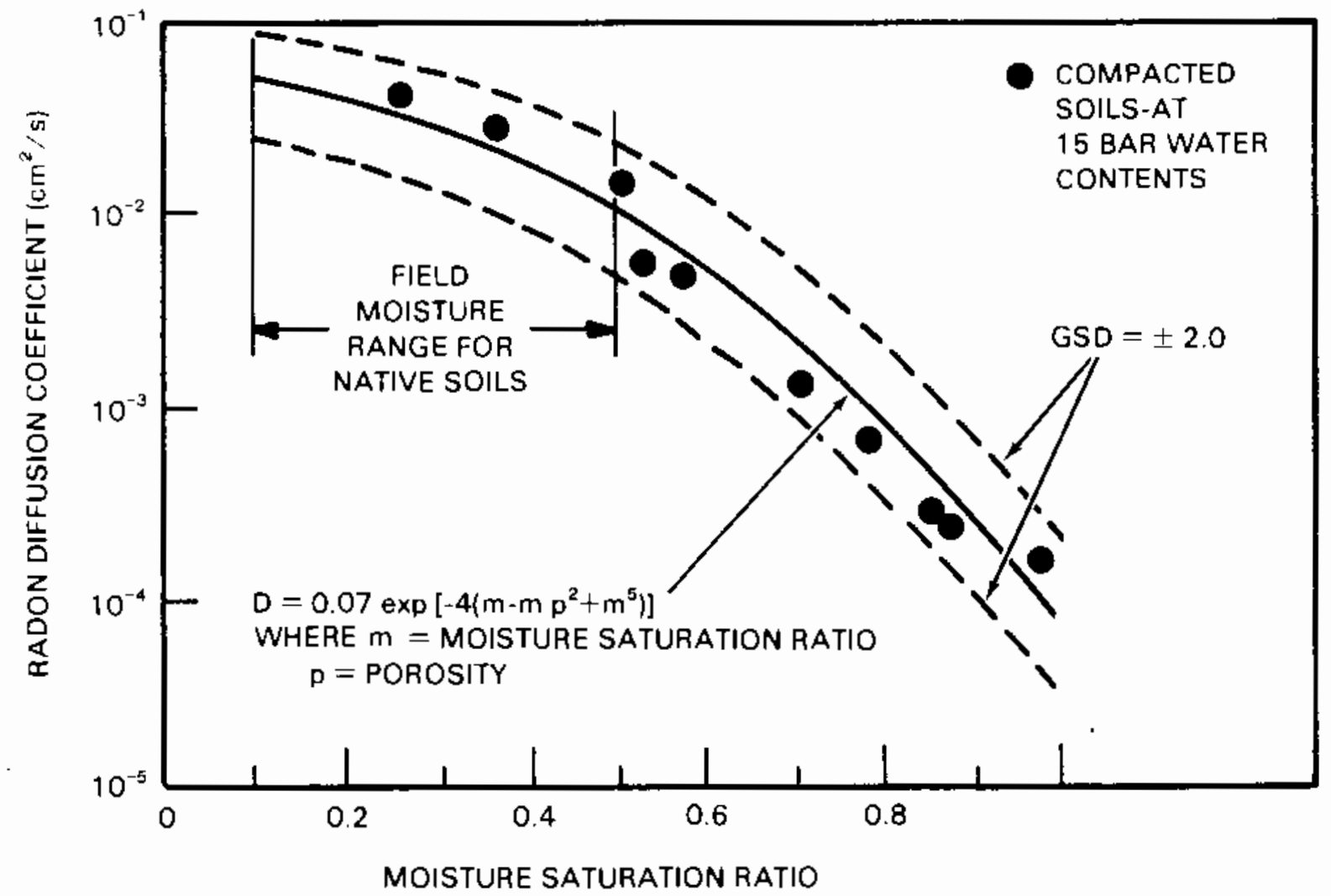

FIGURE 4. Radon Diffusion Coefficients as a Function of Moisture Saturation for Pit-Run Soil Materials Compacted to $>85 \%$ Proctor Density and Equilibrated at 15-Bar Water Content (permanent wilting point) 
. 


\section{PREDICTIONS OF LONG-TERM MOISTURE}

Prediction of long-term moisture saturation in earthen covers at mill tailings sites requires consideration of factors controlling moisture distribution in soil. Several ievels of analysis can be performed depending upon the amount of information available. The most comprehensive analysis is based on detailed modeling of the physical processes that govern soil-moisture movement. This involves detailed analysis of climate, plant and soil variables which control the processes of evaporation, transpiration, infiltration and redistribution. Effects of layering and compaction on residual moisture can readily be incorporated into a detailed model. Such an analysis requires a large amount of input data (e.g., detailed daily weather records, plant transpiration functions, soil hydraulic properties, etc.). Often, this level of information is not readily available, hence a lower level of analysis may be required. Empirical correlations, based on long-term weather records and existing on-site field-moisture conditions, may be suitable in some cases for predicting long-term moisture conditions in earthen covers. Finally, generalized soil and climate characteristics may provide an initial estimate of the expected long-term soil moisture. We will discuss each of these three types of analysis in turn.

\section{DETAILED SIMULATIONS}

Computer modeling provides a useful tool for predicting water movement and storage in soils. To predict long-term moisture contents in a cover, we need input data on climatic variables (precipitation, temperature, humidity) as we 11 as plant extraction factors and soil hydraulic properties. Detailed discussion of this kind of model is provided by Gupta et al (1979) and Simmons and Gee (1981). Somewhat less sophisticated computer models are also available (Knisel 1980, Schroeder et al. 1984) but we have found them to be less useful in predicting soil moisture, particularly under arid site conditions (see Gee and Kirkham 1984 and Thompson and Tyler 1984).

Simulation of water withdrawal by plants in the top $1-m$ of a soil cover using the UNSAT-1D water flow code (Simmons and Gee 1981; Mayer et al. 1981) 
demonstrated that plants could significantly affect the moisture saturation level throughout the root zone. Simulations of over 5 years of climatic variations at Grand Junction, Colorado, indicate that wetted soils can dry to saturation levels of less than $0.3 \mathrm{~m}$ to depths exceeding $1-m$ (Figure 5). Field data from the 1981 earthen cover test site at Grand Junction (Hartley et al. 1983; Freeman, Hartley and Gee 1984) indicate that dry soil placed uncompacted on the pile, in a dry site, exhibits little moisture content change with depth (except at the surface). At Grand Junction, this is thought to be caused largely by the dispersion of the adobe soil by rainfall and subsequent sealing of the top few centimeters, which severely inhibits infiltration, promotes runoff, and also restricts plant growth. It should be noted that for the 1981 field test, the earthen cover plots were nearly bare of vegetation and, therefore, do not test the maximum soil drying expected at this site. Nevertheless, the data from model simulation are in general agreement with measured moisture values (Hartley et aT. 1983).

\section{EMPIRICAL CORRELATION}

To provide an alternative to detailed model simulation, an empirical relationship was developed by RAE for estimating long-term soil moisture (Rogers et al 1982a, Rogers, Nielson and Kalkwarf 1984). The preliminary calculations to estimate long-term soil moisture were based on environmental assessment reports, on file with the U.S. Nuclear Regulatory Commission, for a number of uranium taflings sites in the western United States. Over 400 soil samples whose moisture content had been measured were put into the data base. Data on field (bulk) density and soil texture, either measured or estimated, were also input into the data base. Depth to water table was estimated at each site as was the annual water evaporation and precipitation.

The simple soil/climate correlation yields predicted long-term soil moistures ranging from $m=0.2$ to 0.6 . The correlation is

$$
m=a\left(0.124 p^{1 / 2}-0.0012 \varepsilon-0.04+0.156 f_{c l}\right)+b
$$




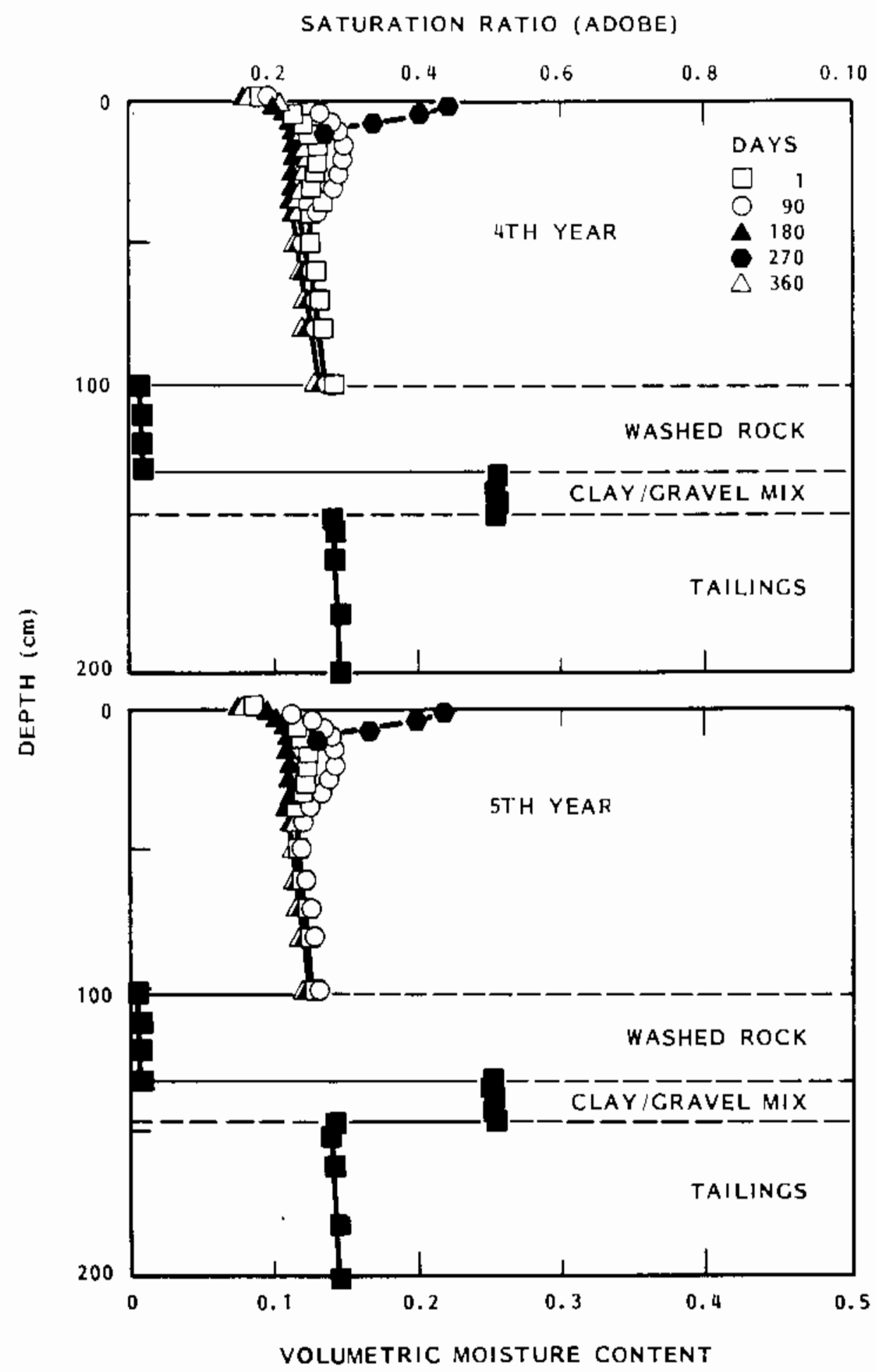

FIGURE 5. Simulated Water Content Profiles for a Multilayered Earthen Cover After 4 and 5 years of Dry Climatic Conditions at Grand Junction, Colorado (after Mayer et al. 1981) 


$$
\text { Where } \begin{aligned}
m & =\text { moisture saturation ratio (see Appendix A) } \\
P & =\text { annual precipitation (inches) } \\
E & =\text { annual lake evaporation (inches) } \\
f_{C l} & =\text { soil material passing a No. } 200 \text { U.S. Standard Sieve. } \\
a & \left.=1-\left(\frac{0.7+f}{H}\right)^{2}\right)^{2} \\
D & =\left(\frac{0.7+f}{C l}\right)^{2} \\
H & =\text { depth to water table (feet). }
\end{aligned}
$$

\section{GENERALIZED SOIL AND CLIMATE ESTIMATE}

If little site specific data are avatiable or if scoping calculations are needed, estimates can be made using generalized soil and climate data. Soil moisture estimates can be made based on textural analysis and known water retention characteristics and estimated field density relationships. For arid sites (25 $\mathrm{cm}$ annual precipitation or less), it can be assumed that soils will be dry most of the year and that plants extract water to wilting throughout the top $3 \mathrm{~m}$ of soil. We assume this same condition will occur on an earthen cover after plants are established. The moisture content at wilting is estimated from laboratory-measured water contents taken from soils drained under 15-bars applied pressure using methods described by Richards (1965). This 15-bar water content appears to be an upper estimate of field moisture at the wilting point of many agricultural crops. Lower water contents may be expected for desert plants; hence, sites where extremely dry conditions persist (<15 cm annual precipitation) should be given special consideration.

At sites where more 25 to $50 \mathrm{~cm}$ of rainfall occur, conditions of drought may occur part of the year. The soil moisture near the surface will cycle through a range from field capacity $(a)$ to pemanent wilting, hence, the annual

(a) Field capacity is defined here to mean the early-spring maximum water content found in the root zone. 
moisture will tend to be higher than the 15-bar water content. For medium to fine texture soils, field capacity has been estimated from 0.3-bar pressure plate data determined in the laboratory in the same manner as the 15-bar water contents (see Richards, 1965). At sites where rainfall is in excess of $50 \mathrm{~cm}$, conditions are wet enough that the field capacity persists for a significant amount of time during the year. Under these conditions, a 0.3-bar water content may be a good estimate of the long-term moisture condition of the site.

Table 2 shows moisture estimates based on the above considerations. The effects of texture are shown in the table in terms of soils containing varying amounts clay. These soil texture-moisture relationships show general trends, which were developed from a very extensive soils data base (Rawls, Brackensick and Saxton 1982). The data base used represents over 1300 different soil types, containing over 5300 individual soil samples from various soil horizons. From this same data base, a correlation was developed between the 15-bar water content and the soil clay percentage. This relationship, expressed as a moisture saturation ratio, is

$$
m_{15}=(0.026+0.005 \mathrm{clay} \%+0.01580 . M . \%) / P
$$

$$
\text { where } \begin{aligned}
m_{15} & =\text { saturation ratio at } 15 \text { bars } \\
0 . M_{.} \% & =\text { soil organic matter content in } \% \\
P & =\text { total porosity. }
\end{aligned}
$$

This relationship was tested on samples of 20 soils, which were located adjacent to 13 UMTRAP sites (Table 3). Determinations of the organic matter were not available, but it was expected to be low because the test samples were taken from a subsample of material ranging in depth from 0.2 to $1 \mathrm{~m}$. For calculation purposes, the organic matter for all samples was fixed at $0.5 \%$. Except for samples from wet sites (Loman, Idaho; Canonsburg, Pennsylvania; and Falls City, Texas), the prediction of the 15-bar water content was reasonable using Equation (1), with predicted values generally within $20 \%$ of the measured values. 
TABLE 2. UMTRAP Sites and Expected Long-Term Saturation Levels Based on Generalized Soils and Climate Data

\begin{tabular}{|c|c|c|c|}
\hline \multirow[b]{2}{*}{ Area } & \multicolumn{3}{|c|}{ Saturation Ratio of Soils } \\
\hline & $\begin{array}{c}\text { Sand } \\
(10 \% \text { Clay })\end{array}$ & $\begin{array}{c}\text { Silt } \\
(20 \% \text { Clay }) \\
\end{array}$ & $\begin{array}{c}\text { Clay } \\
(30 \% \text { Clay })\end{array}$ \\
\hline $\begin{array}{l}\text { Colorado Plateau } \\
\text { Ambrosia Lake } \\
\text { Grand Junction } \\
\text { Green River } \\
\text { Mexican Hat } \\
\text { Monument Valley } \\
\text { Shiprock } \\
\text { Slick Rock } \\
\text { Tuba City }\end{array}$ & $0.2 \pm 0.1$ & $0.3 \pm 0.1$ & $0.5 \pm 0.1$ \\
\hline $\begin{array}{l}\text { West Slope } \\
\text { Durango } \\
\text { Gunnison } \\
\text { Lake View } \\
\text { Lowman } \\
\text { Maybell } \\
\text { Naturita } \\
\text { Rifle } \\
\text { Salt Lake }\end{array}$ & $0.3 \pm 0.1$ & $0.5 \pm 0.1$ & $0.6 \pm 0.1$ \\
\hline $\begin{array}{l}\text { Northern Great Plains } \\
\text { Belfield } \\
\text { Bowman } \\
\text { Converse County } \\
\text { Riverton }\end{array}$ & $0.4 \pm 0.1$ & $0.6 \pm 0.1$ & $0.8 \pm 0.1$ \\
\hline Other & & & \\
\hline $\begin{array}{l}\text { Canonsburg } \\
\text { Falls City }\end{array}$ & $\begin{array}{l}>0.4 \pm 0.1 \\
>0.4 \pm 0.1\end{array}$ & $\begin{array}{l}>0.6 \pm 0.1 \\
>0.6 \pm 0.1\end{array}$ & $\begin{array}{l}>0.8 \pm 0.1 \\
>0.8 \pm 0.1\end{array}$ \\
\hline
\end{tabular}

* These represent generalized soil textures. Sand $=$ soils with approximately 0 to $10 \%$ clay; Silt = soils with 10 to $30 \%$ clay; clay $=$ soils with clay contents in excess of $30 \%$.

\section{FIELD OBSERVATIONS}

Data on long-term moisture in covers at mill tailings sites are limited. The Grand Junctions pile is the only known site where extensive testing of earthen covers have been completed, and data there are limited to about 3 years of testing (Hartley et al. 1983). Long-term predictions for these cover 
TABLE 3. Moisture Saturation at 15-Bar Water Content for 20 Soil Samples Taken Adjacent to UMTRAP Sites

15-Bar Water Content

Sample(a) Soil Texture ${ }^{(b)}$ Clay, $\%$ Measured Predicted $(c)$ Measured

$\begin{array}{llrlll}\text { GJ1 } & \text { Loam } & 17 & 0.20 & 0.23 & 0.87 \\ \text { GJ3 } & \text { Sandy Clay Loam } & 24 & 0.27 & 0.33 & 0.82 \\ \text { GJ4 } & \text { Silt Loam } & 21 & 0.21 & 0.25 & 0.84 \\ \text { NA1 } & \text { Sandy Loam } & 16 & 0.25 & 0.26 & 0.96 \\ \text { MB1 } & \text { Loamy Sand } & 5 & 0.11 & 0.13 & 0.85 \\ \text { DU1 } & \text { Loam } & 14 & 0.20 & 0.21 & 0.95 \\ \text { DU3 } & \text { Clay } & 48 & 0.48 & 0.53 & 0.91 \\ \text { RM1 } & \text { Sandy Loam } & 5 & 0.14 & 0.13 & 1.08 \\ \text { FA1 } & \text { Loamy Sand } & 10 & 0.22 & 0.19 & 1.16 \\ \text { GR1 } & \text { Sandy Loam } & 10 & 0.13 & 0.18 & 0.72 \\ \text { KA1 } & \text { Loamy Sand } & 7 & 0.12 & 0.15 & 0.80 \\ \text { MV1 } & \text { Sandy Loam } & 7 & 0.06 & 0.16 & 0.38 \\ \text { MV2 } & \text { Sandy Loam } & 10 & 0.15 & 0.21 & 0.71 \\ \text { RI1 } & \text { Sandy Loam } & 13 & 0.25 & 0.22 & 1.14 \\ \text { RI3 } & \text { Sandy Loam } & 10 & 0.17 & 0.19 & 0.90 \\ \text { B03 } & \text { Silty Clay Loam } & 38 & 0.40 & 0.43 & 0.93 \\ \text { CA1 } & \text { Loam } & 14 & 0.33 & 0.23 & 1.43 \\ \text { L01 } & \text { Loam } & 17 & 0.32 & 0.24 & 1.33 \\ \text { FC1 } & \text { Sandy Clay } & 35 & 0.55 & 0.39 & 1.41 \\ \text { FC2 } & \text { Clay } & 41 & 0.56 & 0.45 & 1.24\end{array}$

(a) Sample Locations: GJ (Grand Junction, CO), NA (Naturita, CO), MB (Maybell, CO), DU (Durango, CO), RM and FA (Shiprock, NM), GR (Ambrosia Lake, NM), KA (Monument Valley, AZ), MV (Mexican Hat, UT), RV (Riverton, WY), BO (Bowman/ Belfield, ND), CA (Canonsburg, PA), Lo (Lowman, ID), FC (Falls City, TX). (b) USDA textural classification (Soil Survey Staff 1975). (c) Predicted using Equation (4).

systems, then, must rely on general observations at sites where soil moisture data have been collected, over some time and where conclusions regarding the influence of the climate and soil type can be extrapolated to earthen cover systems under similar conditions. We discuss briefly our general observations about soil moisture variations and describe the long-term moisture changes in soils reported in available literature. Finally, measured soil moisture is compared to calculated saturation ratios using both the empirical climate/soil relationship (Equation 3 ) and the generalized soil relationship (Equation 4) for selected mill tailings piles where earthen cover systems are in place. 
Field water contents of soils vary in time and space. The greatest variability in time is observed near the soil surface because of climatic events (rainfall and evaporation) and the soil subsequently wets and dries. These changes generally are damped out rapidly with depth so that the moisture content changes with time, below the $1-m$ depth, are very slow. Only prolonged rainfall or drought affect the moisture contents at these depths more than a few percent, and changes occur slowly over several weeks or months. Water at depth can be removed slowly in response to plant water removal in arid and semiarid climates.

Figure 3 shows the seasonal water content changes in a soil profile for a relatively sandy soil at a semiarid grassland site in Colorado (Galbraith 1971). The data suggest that for this sandy soil (67\% sand and $19 \%$ clay) the seasonal water penetration is seldom below $1.2 \mathrm{~m}$. For a long-term drought situation at a shelterbelt site in North Dakota, Willis et al. (1976) have shown that significant moisture changes occur at depths to $3 \mathrm{~m}$, which can be attributed to tree root uptake (Figure 6). Similar data showing long-term moisture at depth $(2$ to $3-m)$ staying relatively constant in time have been obtained from a study of coal-mine reclamation sites near Beulah, North Dakota (Shroeder and Baver, 1984). Water content changes with time (24 months and longer) have been reported for soil from arid and semiarid sites in Rock Valley, Nevada (Romney et al. 1973), Washtucna, Washington (Campbell and Harris 1977), Center, North Dakota (Baver, Gee and Gilley 1975), and Grand Junction, Colorado (Hartley et al. 1983). Figure 7 indicates that moisture saturation in the top 1 to $3 \mathrm{~m}$ seldom exceeds 0.6 and typically ranges from 0.2 to 0.4 , depending on soil type and rainfall distribution. At Grand Junction, Colorado, the annual average moisture saturation ratio was below 0.3 for the entire 24-month period. Additional data from this site support the observations of little moisture change below $1-m$ depth for periods as much as 3 years.

Surface moisture ( 0 to $0.3 \rightarrow$ depth) samples have been taken periodically at Grand Junction, Colorado, and several other sites. The data have shown that moisture changes do not occur rapidly except near the soil surface, seldom below $0.3 \mathrm{~m}$, and then only if the soil is relatively coarse. Table 4 compares the average moisture saturation at four sites where cover has been respread on 


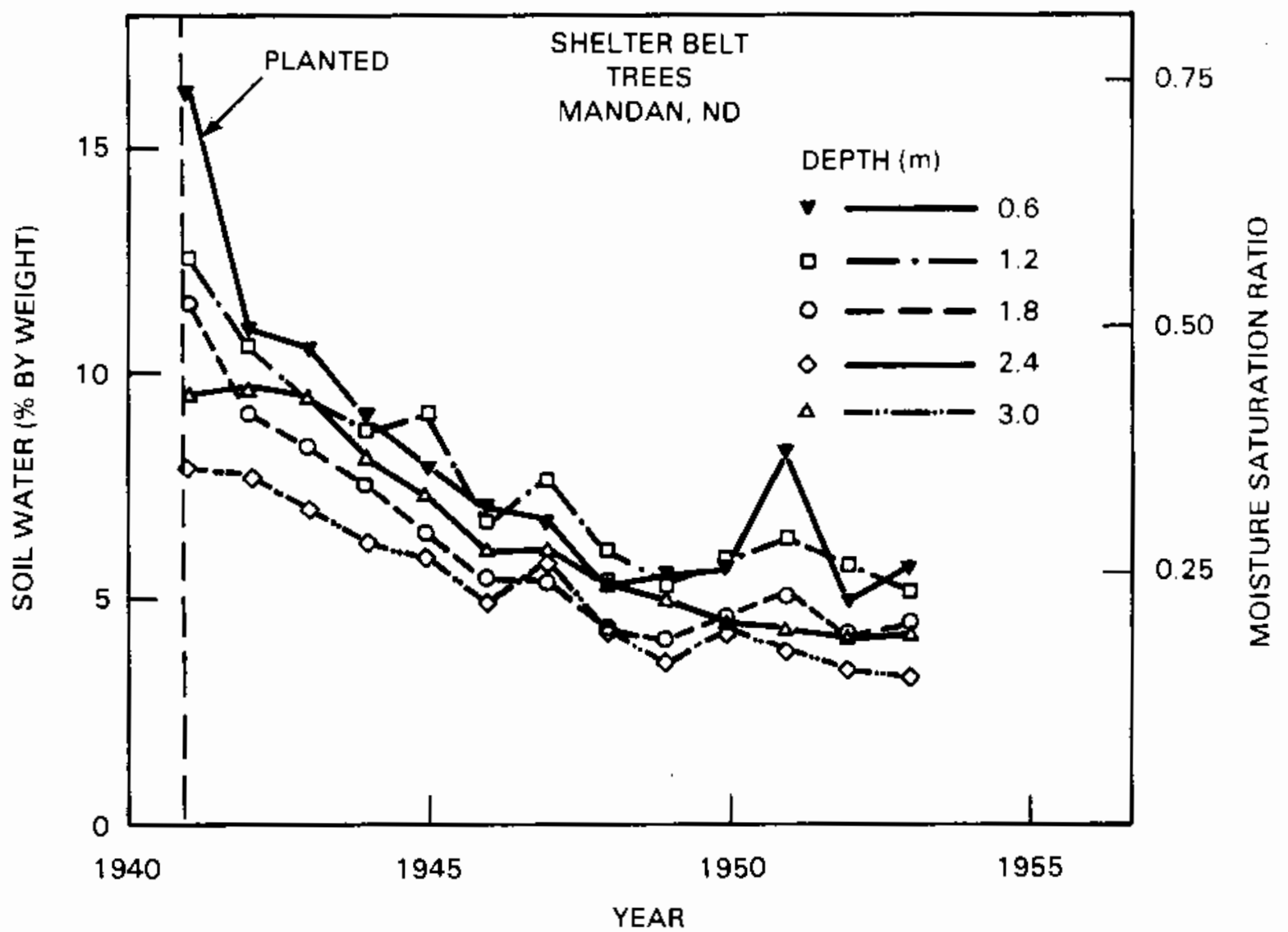

FIGURE 6. Changes in Moisture Saturation Levels with Time in Soil at Selected Depths Below Shelterbelt Trees Near Mandan, North Dakota (after Willis et al. 1976) 


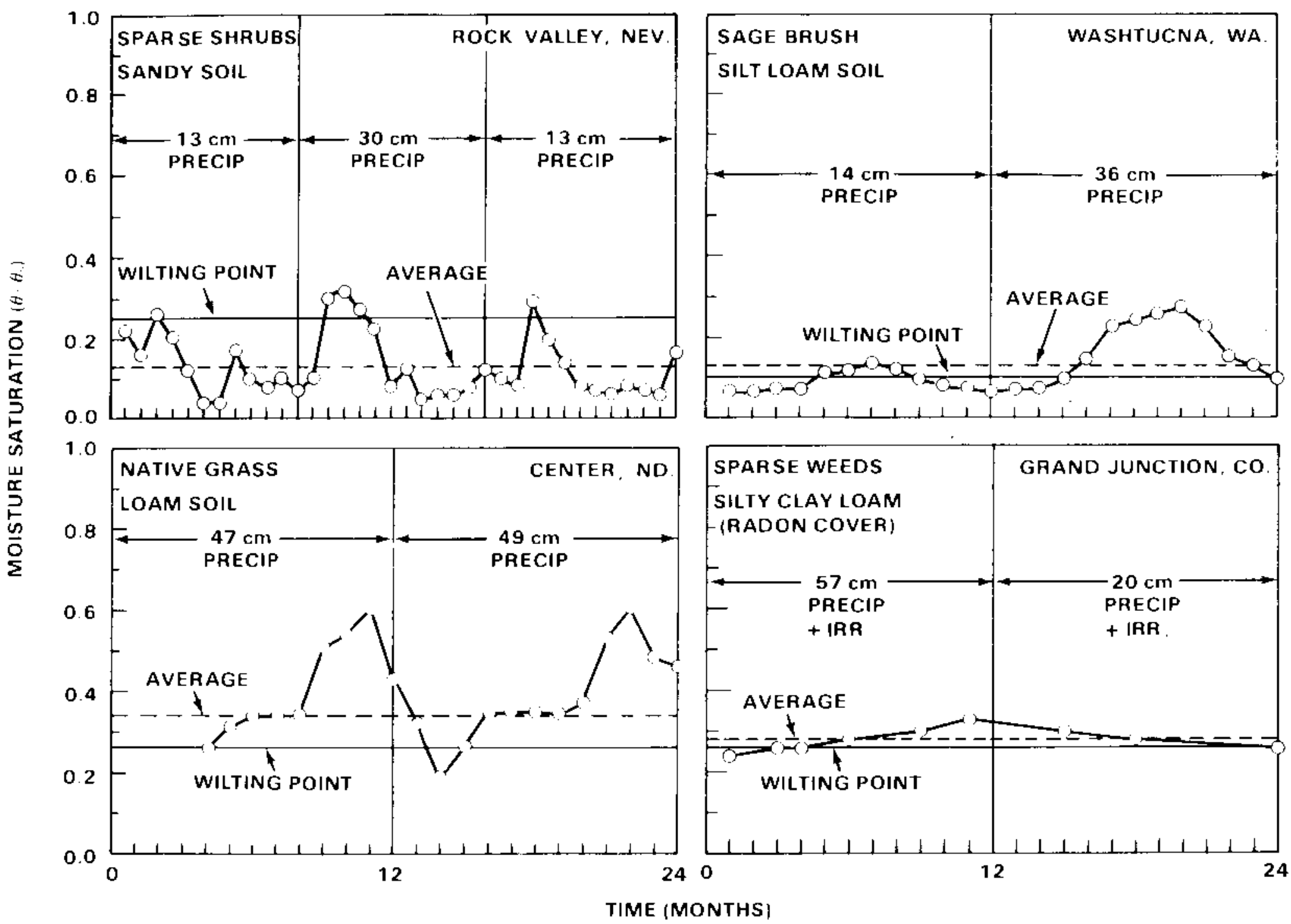

FIGURE 7. Moisture Saturation for 24-Month Periods for Surface Soils at Arid and Seriarid Sites Where Data Are Available from the Literature. Data taken from Romney et al. (1973), Campbell and Harris (1977), Bauer et al. (1976), and Hartley et al. (1983). 
TABLE 4. Average Moisture Saturation in Meters in the Top $0.3 \mathrm{~m}$ of Earthen Cover Materials Overiying Four Uranium Mill Tailings Piles Compared to 15 Bar Measurement (Equation 4) and $\mathrm{Cl}$ imate/Moisture Correlation (Equation 3)

\begin{tabular}{|c|c|c|c|c|}
\hline Location & Oct/Nov 1982 & June 1983 & $\begin{array}{c}\text { Empirical } \\
\text { Correlation } \\
\end{array}$ & 15-Bar Value \\
\hline Monticello, Utah & 0.18 & $\rightarrow$ & 0.5 & 0.26 \\
\hline Shiprock, New Mexico & 0.14 & -- & 0.32 & 0.14 \\
\hline Riverton, Wyoming & 0.45 & - & 0.35 & 0.24 \\
\hline Grand Junction, Colorado & 0.24 & 0.27 & 0.42 & 0.34 \\
\hline
\end{tabular}

tailings and the soil has equilibrated with the environment. In all cases, the soil was relatively shallow $(1 \mathrm{~m})$. The data indicate that at the drier sites (e.g., Shiprock and Grand Junction), there are periods of time during the year when the moisture at the surface drops well below the 'permanent wilting point' (15-bar percentage). Measurements on thicker soil covers (more than $1 \mathrm{~m}$ ) should provide better analysis of soil moisture storage at tailings sites. 
. 


\section{COVER DESIGN FOR LONG-TERM MOISTURE}

Based on our knowledge of soil moisture and compaction relationships, it is possible to conceptualize a cover system that can incorporate features which optimize soil moisture levels. Our study with pit-run material indicates a compacted soil that can maintain a saturation ratio in excess of 0.6 appears to be best suited as a radon barrier. Fine-textured pit-run shale and clay materials appear to be suitable for radon barrier systems. Although compaction is a desirable feature for radon control, it severely inhibits root growth. A site requiring vegetation for long-term stabilization likely will require at least $1 \mathrm{~m}$ of uncompacted surface soil. Placing moist, compacted soil at depth will also help prevent long-term dessication or de-densification of the compacted zone. In considering all features of the earthen cover system, the final cover design at a vegetated site will likely be a two-layer cover system with the plant root zone located in uncompacted soil and the compacted layer (radon barrier) located below the root zone. A similar cover design has proven effective at the Grand Junction field test site where compacted layers are located more than 1-m below the surface. Compacted earthen cover systems at this site have continued to perform well and at present, meet the EPA radon guidelines (Freeman, Hartley and Gee 1984). 
4

$\mathbf{3}$ 
This study has indicated the following:

- Soil moisture and compaction are the key design features for radon control using earthen covers.

- Long-term moisture predictions can be made using detailed model simulations or simplified correlations. The accuracy of these predictions cannot be verified because field studies have only a limited (3-year) test period.

- Pit-run fine-textured materials, wetted, and compacted to near optimum moisture and density should prove to be suitable radon barrier materials for earthen cover systems. Long-term moisture conditions can be preserved in these materials by covering them with a $1-m$ thick uncompacted soil that can serve as a root zone for plant growth. 
-

-

\section{.}




\section{REFERENCES}

Bauer, A., G. W. Gee and J. E. Gilley. 1976. Physical, Chemical and Biological Aspects of Strip-Mined in Western North Dakota. Final report to old West Regional Commission, North Dakota State University, Fargo, North Dakota.

Campbell, G. S., and G. A. Harris. 1977. "Water Relations and Water Use Patterns for Artemisia tridentata nutt. in Wet and Dry Years." Journal of Ecology 58:652-659.

Environmental Protection Agency. 1983. "Environmental Standards for Uranium and Thorium Mill Tailings at Licensed Commercial Processing Sites; Final Rule." Federal Register, Friday October 7, 1983, Vol. 48(196), $45926-45 \overline{947 .}$

Freeman, H. D., J. N. Hartley and G. W. Gee. 1984. "Radon Barrier Field-Test Monitoring at Grand Junction Tailings Pile." In Proceedings of the Sixth Symposium on Uranium Mill Tailings Management, Civit Engr. Dept., Colorado State Unfversity, Ft. Collins, Colorado.

Galbraith, A. F. 1971. "The Soil Water Regime of a Shortgrass Prairie Ecosystem." Colorado State University Ph.D. Dissertation, Univ. Microfilms, Ann Arbor, Michigan.

Gee, G. W., J. T. Zellmer, M. E. Dodson, R. R. Kirkham, B. E. Opitz, D. R. Sherwood and J. Tingey. 1981. "Radon Control by Multilayer Earth Barriers: II. Field Tests." In Fourth Symposium on Uranium Mill Tailings Management, pp. 289-307, Civil Engineering Department, Colorado State University, Ft. Collins, Colorado.

Hartley, J. N., G. W. Gee, E. G. Baker and H. D. Freeman. 1983. 1981 Radon Barrier Field Test at Grand Junction Uranium Mill Tailings Pile. DOE/UMT-0213 (PNL-4539), Pacific Northwest Laboratory, Richland, Washington.

Herbel, C. H., and L. H. Gile. 1973. "Field Moisture Regimes and Morphology of Some Arid-Land Soils in New Mexico." In Field Soil Water Regime, ed. R. R. Bruce, pp. 119-152, SSSA Special Pubijcation Series 5, Soil Sci. Soc. Am., Madison, Wisconsin.

Knisel, W. G., Jr. (ed). 1980. CREAMS: A Field Scale Model for Chemicals, Runoff and Erosion from Agricultural Management Systems. U.S. Department of Agriculture, Conservation Research Report No. 26 , Washington, D.C.

Mayer, D. W., C. A. Oster, R. W. Nelson and G. W. Gee, 1981. Radon Diffusion Through Multilayer Earthen Covers: Models and Simulations. DOE/UMT-0204 (PNL-3989), Pacific Northwest Laboratory, Richland, washington. 
Nielson, K. K., D. C. Rich, V. C. Rogers and D. R. Kalkwarf. 1982. Comparison of Radon Diffusion Coefficients Measured by Transient Diffusion and SteadyState Laboratory Methods. NUREG/CR-2875, U.S. Nuclear Regulatory Commission, Washington, D.C.

NOAA. 1979. Climatic Atlas of the United States. National 0ceanic and Atmospheric Administration, Washington, D.C.

Rawls, H. D., D. L. Brakensiek and K. E. Saxton. 1982. "Estimation of Soil Water Properties." Transactions of the American Society of Agricultural Engineers 25(5):1316-1320, 1328 .

Richards, L. A. 1965. "Physical Condition of Water in the Soil." In C. A. Black (ed.). Methods of Soil Analysis. Part 1. pp. 128-152. American Society of Ágronomy Monograph, Madison, Wisconsin.

Rogers, V. C., K. K. Nielson and D. R. Kalkwarf. 1984. Radon Attenuation Handbook for Uranium Mill Tailings Cover Design. NUREG/CR-3533 (PNL-4878), U.S. Nuclear Regulatory Commission, Washington, D.C.

Rogers, V. C., K. K. Nielson and D. C. Rich. 1981. Ambient Soil Moistures in Western Uranium Milling Regions. RAE-9-4, Report to Pacific Northwest Laboratory, Rogers and Associates, Salt Lake City, Utah.

Rogers, V. C., K. K. Nielson, D. C. Rich, G. M. Sandquist and M. L. Mauch. 1982a. Radon Attenuation with Earthen Covers. RAE-33-14, Rogers and Associates, SaTt Lake City, utah.

Rogers, V. C., K. K. Nielson, D. C. Rich and G. B. Merrell. $1982 b$. "Measurement and Calculations of Radon Flux Attenuation by Western U.S. Soils." In Proceedings of the Fifth Symposium on Uranium Mill Tailings Management, pp. 369-382, Colorado State University, Fort Collins, Cotorado.

Romney, E. M., V. 0. Hale, A. Wallace, 0. R. Lunt, J. D. Childress, H. Kaas, G. V. Alexander, J. E. Kinnear and T. L. Ackerman. 1973. Some Characteristics of Soil and Perennial Vegetation in Northern Mojave Desert Areas of the Nevada Test Site. UCLA 12-916. Laboratory of Nuclear Medicine and Radiation Biology, Los Angeles, California.

Schroeder, S. A., and A. Bauer. 1984. "Soil Water Variation in Spoil and Undisturbed Sites in North Dakota." Soil Sci. Soc. An. J. 48:656-659.

Schroeder, P. R., S. M. Morgan, T. M. Walski and A. C. Gibson. 1984. The Hydrologic Evalution of Landfill Performance (HELP) Moder Vol. 1, User's Guide for Version 1. EPA/530-SW-84-009, U.S. Environmental Protection Agency, Cincinnati, ohio.

Simmons, C. S., and G. W. Gee. 1981. Simulation of Water Flow and Retention in Soil Layers Overlying Uranium Mill Tailings. D0E/UMT-0203 (PNL-3877), Pacific Northwest Laboratory, Richland, Washington. 
Soil Survey Staff. 1975. Soil Taxonomy, Agricultural Handbook 436. Soil Conservation Service, U.S. Department of Agriculture, Washington, D.C.

Thompson, F. L., and S. W. Tyler. 1984. Comparison of Two Groundwater Flow Models (UNSATID and HELP) and Their Application to Covered Fly Ash Disposal Sites. EPRI Document Series, August 1984, ETectric Power Research Institute, Palo Alto, California.

Willis, W. 0., A. B. Frank, E. J. George and J. J. Haas, 1976. "Soil Water Extraction by and Growth of Multi-Row Wind Breaks." In Proceedings of the Symposium: Shelterbelts on the Great Plains, ed. R. W. Tinus, Great Plains Agricultural Council Publication 78:87-92 Fargo, North Dakota. 
v 


\section{APPENDIX A}

SOIL MOISTURE, DENSITY, POROSITY, AND RADON DIFFUSION CALCULATIONS 
APPENDIX A

SOIL MOISTURE, DENSITY, POROSITY, AND RADON DIFFUSION CALCULATIONS

One of the most important, but often misunderstood, relationships in earthen cover design is the influence of moisture content on radon diffusion. It has been known for some time that increased soil moisture can cause decreased radon diffusion from earthen covers and that an inverse relationship exists between the radon diffusion coefficient and soil water content (Tanner 1964, 1980; Kraner, Schroeder and Evans 1964; Rogers, Overmyer and Nielson 1979). What has not been clearly addressed in the past, is the effect of soil compaction (bulk density) on the moisture content. For example, the EPA (1983) has calculated cover thickness based solely on soil moisture content estimates with no mention of soil density, nor its influence on moisture content. often it is not clear in discussions of moisture effects on radon diffusion whether the moisture calculation is based on a wet or dry, weight or volume percent basis (e.g., Tanner 1964; Rogers, Overmyer and Nielson 1979; EPA 1983).

The purpose of this appendix is to provide basic expressions for soil properties (moisture, density, porosity) and to discuss the use of recently developed empirical relationships correlating soil moisture and radon diffusion coefficients. These latter expressions are those likely to be used by mill operators and others to design earthen covers for radon controi at mill tailings sites.

The following expressions may be used to describe the relationships between soil moisture and soil bulk density and porosity. Detailed discussions of these and other soil property relationships can be obtained from standard text books on soil mechanics and soil physics (e.g., Das 1979; Hillel 1981).

BASIC EXPRESSIONS FOR SOIL PROPERTIES

1. Soil moisture expressions:

$M_{d}=$ dry $w t \%=100 \times$ mass of water/mass of oven dry soil

$M_{w}=$ wet $w t \%=100 \times$ mass of water/mass of wet soil

$\theta=$ volumetric water content $=$ volume of water/volume of soil 


$$
\begin{aligned}
m= & \text { moisture saturation or saturation ratio = volumetric water } \\
& \text { content/total porosity }
\end{aligned}
$$

Figure A.1 shows the relationship between the dry-and wet-weight moisture content and the saturation ratio for silt-and sand-textured soils that have distinctiy different bulk densities. Silty (fine-textured) soils tend to have lower densities, hence greater porosities than sandy soils. The net result is that for the same moisture percentage (computed on either a dry or wet weight basis) the moisture saturation ratio, $m$, is greater for sand than for silt. It should also be noted that differences between wet and dry weight moisture percentages are greater for the silt than the sand due to the lower density of the silt. Composited materials, sand and silt mixtures, typical of some pitrun soils may have densities considerably higher than any of the individual soil fractions.

2. Soil density expressions:

$$
\begin{aligned}
\rho_{b} & =\text { dry bulk density }=\text { mass of dry soil/total volume } \\
\rho_{s} & =\text { particle density }=\text { mass of dry soil/total volume } \\
P & =\text { porosity }=1-\rho_{b} / \rho_{s} \\
\rho_{b} & =\rho_{s}(1-P) \\
e & =\text { void ratio }=(P / 1-P)
\end{aligned}
$$

3. Interrelationships between moisture, density, and porosity:

$$
\begin{aligned}
M_{d} & =\left[M_{W} /\left(1+M_{d}\right)\right] 100 \\
\theta & =M_{d} / 100 \times \rho_{b} \\
m & =\theta / P \\
\varepsilon_{a} & =P-\theta=\theta[(1-m) / m]=P(1-m)=\text { air-filled porosity }
\end{aligned}
$$

Table A.1 shows the relationship between total porosity, air-filled porosity, and saturation ratio for soil conditions ranging from loosely packed to tightiy compacted soils. At the same air-filled porosity, the saturation may vary from 0.8 to 0.5 as the density increases from 1.35 to $2.16 \mathrm{~g} / \mathrm{cm}^{3}$. 


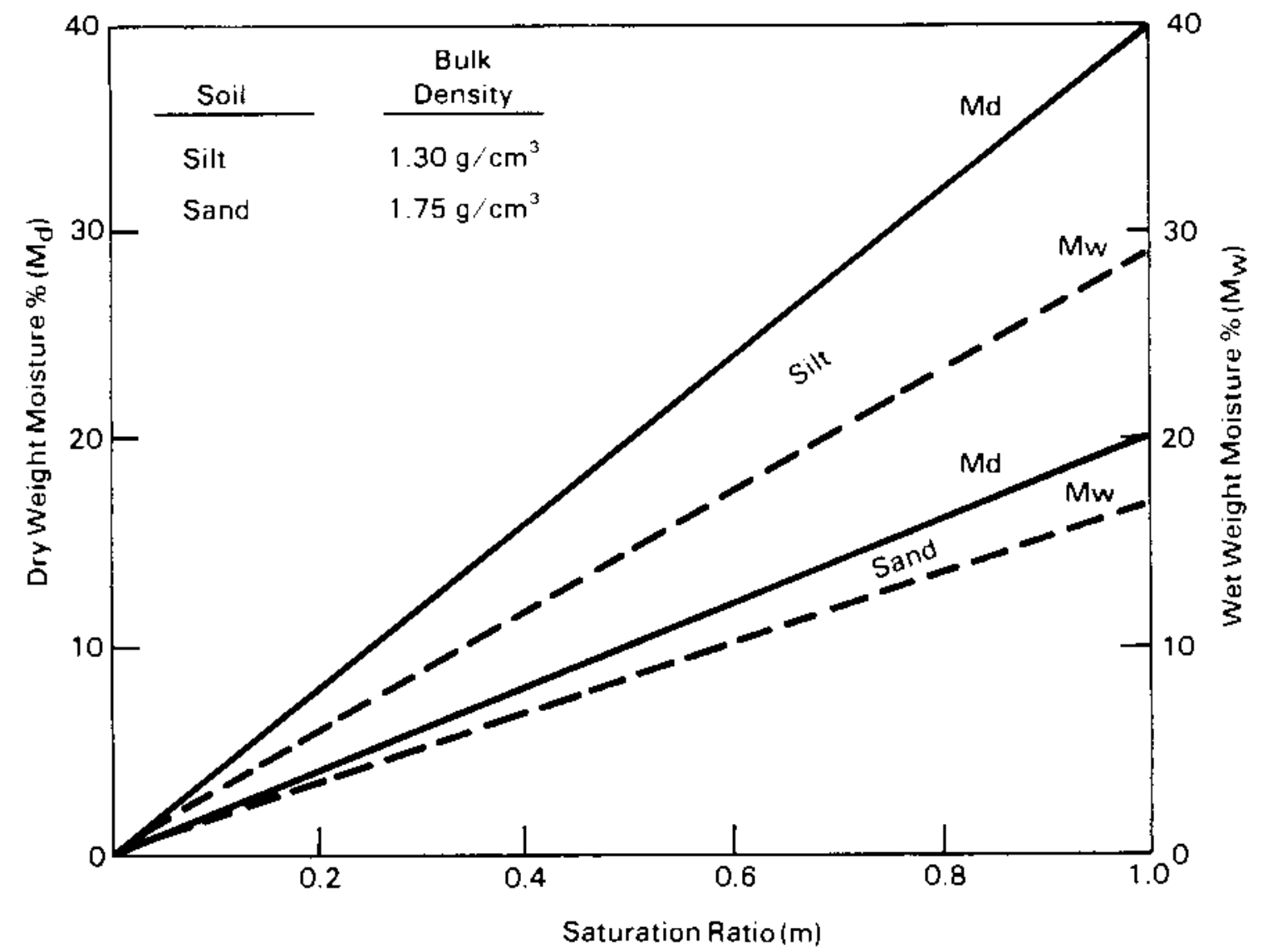

FIGURE A.1. Relationship Between Dry Weight, $M_{d}$, and Wet weight, $M_{w}$, Moisture Percentage, and Moisture Saturation, $m$, for Two Soils. A soil particle density of $2.7 \mathrm{~g} / \mathrm{cm}^{3}$ is assumed.

TABLE A.1. Physical Relationships of Earthen Cover Materials

\begin{tabular}{|c|c|c|c|c|}
\hline $\begin{array}{l}\text { Compaction of } \\
\text { Earthen Cover }\end{array}$ & $\begin{array}{c}\text { Typical } \\
\text { Bulk Denşity, } \\
g / \mathrm{cm}^{3}\end{array}$ & $\begin{array}{c}\text { Total } \\
\text { Porosity, } \\
\mathrm{P} \\
\end{array}$ & $\begin{array}{l}\text { Air-Filled } \\
\text { Porosity, } \\
\text { P- } \theta\end{array}$ & $\begin{array}{c}\text { Saturation } \\
\text { Ratio, } \\
m \\
\end{array}$ \\
\hline $\begin{array}{l}\text { Loose } \\
\text { Moderately Loose } \\
\text { Moderately Dense } \\
\text { Dense }\end{array}$ & $\begin{array}{l}1.35 \\
1.62 \\
1.89 \\
2.16\end{array}$ & $\begin{array}{l}0.5 \\
0.4 \\
0.3 \\
0.2\end{array}$ & $\begin{array}{l}0.1 \\
0.1 \\
0.1 \\
0.1\end{array}$ & $\begin{array}{l}0.80 \\
0.75 \\
0.65 \\
0.50\end{array}$ \\
\hline
\end{tabular}

Radon Diffusion Versus Moisture Content Relationships

It is instructive to note that empirical relationships have been estab$l i$ shed between radon diffusion coefficients and $M_{w}, m$, and $\varepsilon_{A}$ (Rogers, Overmyer and Nielson 1979; Rogers, Nielson and Kalkwarf 1984; and Nelson, Gee and Oster $1980)$. 
The relationship between radon diffusion and wet weight water was developed by Rogers, Overmyer and Nielson (1979) and is expressed as:

$$
D / D_{0}=\exp \left(-0.261 M_{W}\right)
$$

Analysis of the relationship between $M_{w}$ and $D$ indicates that it incorrectly handles changes in bulk density and is appropriate only for the data set that it was correlated with.

The uncertainty in the measured radon diffusion coefficient for soil materials cannot be overemphasized. Figure A.2 shows how this uncertainty [a geometric standard deviation (GSD) of \pm 2.0$]$ in estimating or measuring the radon diffusion coefficient can affect cover thickness estimates. The cover

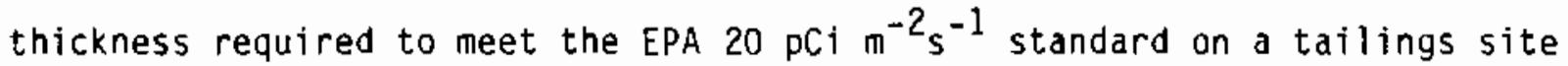
with a bare surface flux of $300 \mathrm{pCi} \mathrm{m} \mathrm{m}^{-2} \mathrm{~s}^{-1}$ is plotted as a function of cover bulk density. Even soils with high moisture contents exhibit high uncertainties (factor of 2) in cover thickness requirements at moderate to low densities.

Based on the observation that density can significantly affect the cover thickness calculation by strongly influencing the moisture saturation, we do not recommend the use of Equation (A.14) for calculating radon diffusion coefficients, particularly if compaction effects are important. After carefu? review of the existing literature, we have determined that two expressions can be used reasonably well to describe the effects of compaction on radon diffusion. The first expression relates radon diffusion to the air filled porosity and was developed by Nelson, Gee and Oster (1980) from existing laboratorymeasured radon diffusion coefficients. The relationship is

$$
D / D_{0}=0.74 \varepsilon_{a}^{1.16}
$$

Nielson et al. (1981) have accurately pointed out that this expression fails to describe radon diffusion in the very wet range for soil moisture, (m>0.95). However, the uncertainties in the wet range, coupled with the fact that normal field soils seldom exceed $m=0.6$, suggest that the air-filled porosity model 


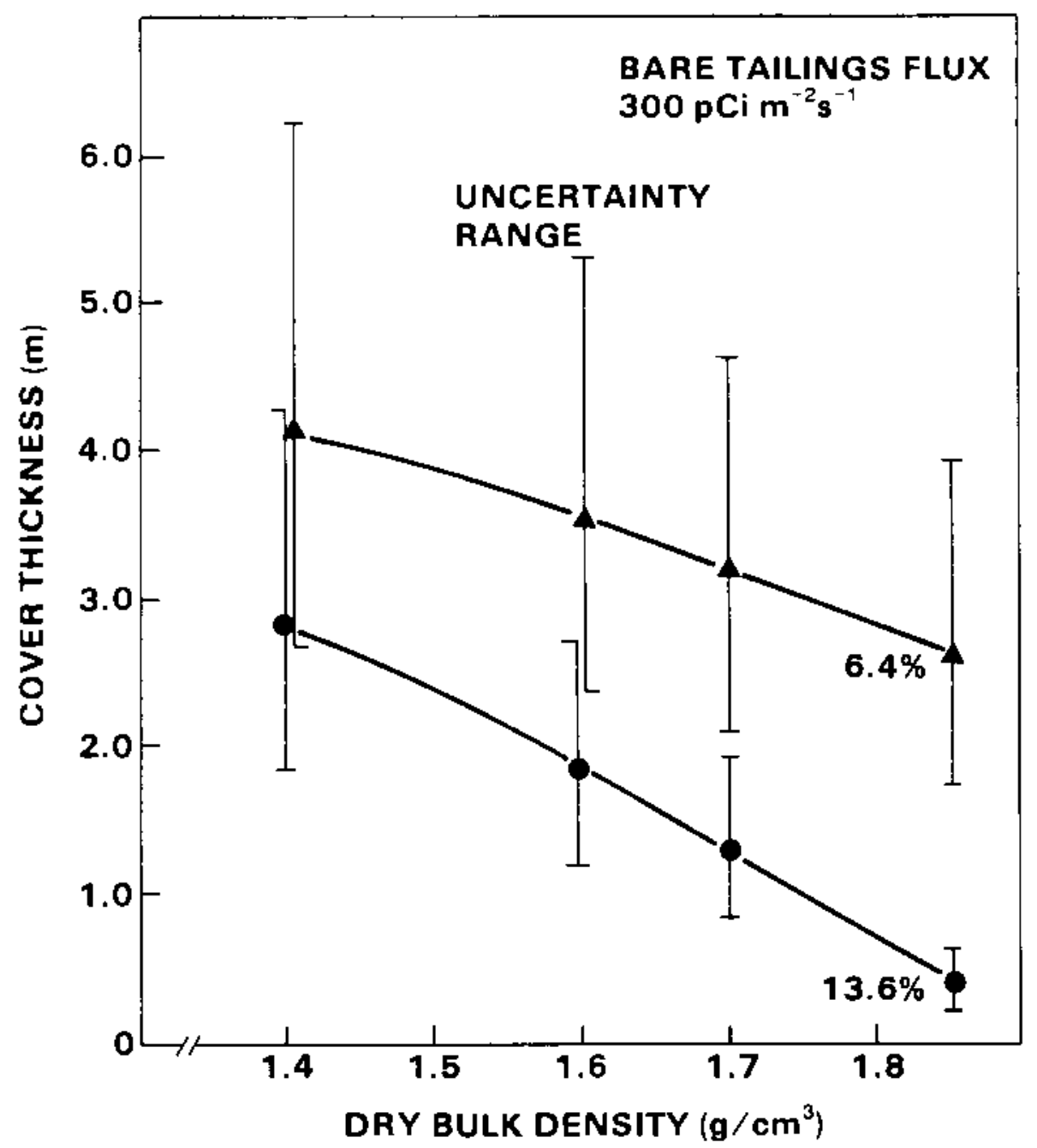

FIGURE A.2. Calculated Cover Thickness as a Function of Dry Bulk Density at Two Soil Moistures

could be used conveniently to describe the effects of moisture saturation on radon diffusion. However, for a cover system that has a wide range in compaction and moisture content the air-filled porosity model may not adequately predict the radon diffusion. As an example, using Equation (A.15) on Table A.1 data produces identical radon diffusion coefficients for all soils listed because the air-filled porosity is the same $\left(5.2 \times 10^{-3} \mathrm{~cm}^{2} / \mathrm{s}\right)$. Our work described in the main text (Figure 4) suggests that radon diffusion coefficients for compacted soils are more directly related to moisture saturation than air-filled porosities; hence, radon diffusion coefficients for compacted soits will more likely be described using Equation (1) as described in the main 
text. Based on the present empirical evidence, we suggest that radon diffusion coefficients for all soil cover systems be calculated using the empirical relationship

$$
D=0.07 \exp \left[-4 m\left(1-p^{2}+m^{4}\right)\right]
$$

By expressing soil moisture in terms of $m$ (the saturation ratio), the soil density relationship is implicitly accounted for because $m$ depends on $\rho_{b}$, the soil bulk density. 
REFERENCES FOR APPENOIX A

Das, B. M. 1979. Introduction to Soil Mechanics. Iowa State University Press, Anes, Iowa.

Environmental Protection Agency. 1983. "Environmental Standards for Uranium and Thorium Mill Tailings at Licensed Commercial Processing Sites; Final Rule." Federal Register, October 7, 1983, Vol. 48(196), 45926-45947.

Hillel, D. 1981. Introduction to Soil Physics. Academic Press New York.

Kraner, H. W. G. L. Schroeder, and R. D. Evans. 1964. "Measurements of the Effects of Atmospheric Variable on Radon-222 Flux and Soil-Gas

Concentration." In The Natural Radiation Environment, J. A. S. Adams and W. M. Lowder, eds., University Chicago Press, Chicago, Ilitinois.

Nielson, K. K., V. C. Rogers, D. C. Rich, F. A. Nederhand, G. M. Sandquist, and C. M. Jensen. 1981. Laboratory Measurements of Radon Diffusion Through Multilayered Cover Systems for Uranium Tailings. D0E/UMT-0206 (PNL-4107), Pacific Northwest Laboratory, Richiand, Washington.

Nelson, R. W., G. W. Gee, and C. A. Oster. 1980. "Radon Control by Multilayer Earth Barriers, 1. Modeling of Moisture and Density Effects of Radon Diffusion from Uranium Mill Tailings." In Uranium Mill Tailings Management, Proceedings of the Third Symposium, pp. 79-88, Colorado State University, Fort Collins, Colorado.

Rogers, V. C., R. F. Overmyer, and K. K. Nielson. 1979. "Radon Attenuation Through Cover Materials," In Proceedings of Second Symposium on Uranium Mill Tailings Management, Colorado State University, Fort Collins, Colorado.

Rogers, V. C., K. K. Nielson and D. R. Kalkwarf. 1984. Radon Attenuation Handbook for Uranium Mill Tailings Cover Design. NUREG/CR-3533 (PNL-4878), U.S. Nuclear Regulatory Commission, Washington, D.C.

Tanner, A. B. 1964. "Radon Migration in the Ground: A Review." In The Natural Radiation Environment, J. A. S. Adams and W. M. Lowder (eds). University of Chicago Press, Chicago, Illinois.

Tanner, A. B. 1980. "Radon Migration in the Ground - A Supplementary Review." In The Natural Radiation Environment III. T. F. Gesell and W. M. Lowder (eds)., Conf 78-0422, University of Chicago, Press, Chicago, Illinois. 


\section{DISTRIBUTION}

No. of

Copies

OFFSITE

J. A. Morley, Project Manager Uranium Mill Tailings Project office

Suite 1700

5301 Central Ave., NE

Alburquerque, NM 87108

J. Themelis

Uranium Mill Tailings Project office

Suite 1700

5301 Central Ave., NE

Albuquerque NM 87108

M. L. Matthews

Uranium Mill Tailings Project office

Suite 1700

5301 Central Ave., NE

Albuquerque, NM 87108

William E. Mott, Director

Environmental Safety Engineering Division

U.S. Department of Energy, EP-14

Washington, DC 20545

27 DOE Technical Information Center

J. E. Baublitz, 0irector

Division of Remedial Action

Projects

Office of Nuclear Waste

Management

U.S. Department of Energy NE-301

Washington, OC 20545
No. of

Copies

E. Delaney

Oivision of Remedial Action Projects

Office of Nuclear Waste

Management

U.S. Department of Energy, $\mathrm{NE}-301$

Washington, DC 20545

D. H. Groelsema

Division of Remedial Action Projects

Office of Nuclear Waste Management

U.S. Department of Energy NE-301

Washington, OC 20545

A. Kluk

Division of Remedial Action Projects

Office of Nulcear Waste Management.

U.S. Department of Energy NE-301

Washington, DC 20545

M. G. White

Oivision of Remedial Action Projects

Office of Nuclear Waste Management

U.S. Department of Energy, $\mathrm{NE}-301$

Washington, DC 20545

J. White, Chief

Waste Management Branch

U.S. Department of Energy

Richland Operations office

P.0. Box 500

Richland, WA 99352 
No. of

Copies

E. L. Keller, Director

Technical Services Division

DOE Oak Ridge Operations

office

P. O. Box E

Oak Rídge, TN 37830

Office of the Assistant Manager for Energy Research and Development

DOE Oak Ridge Operations Dffice P.0. Box E

Oak Ridge, TN 37830

B. Rawles

Battelle Menorial Institute

office of Nuclear Waste

Isolation

505 King Avenue

Columbus, $\mathrm{OH} 43201$

J. Duray

Bendix Field Engineering Corp. P.0. Box 1569

Grand Junction, CO 81502

J. D. Nel son

Colorado State University

211 Weber Building

Fort Collins, CO 80523

T. A. Shepherd

Colorado State University

Water, Waste and Land

1311 So. College Ave.

Fort Collins, CO 80523

F. W. Whicker

Radiology Radiation

Biology Department

Colorado State University

Fort Collins, CO 80521
No. of

Copies

\author{
D. Mills \\ Department of Environmental \\ Protection \\ Commonwealth of Kentucky \\ 18 Reilly Road \\ Frankfort, KY 40601 \\ S. Lichtman \\ Criteria and Standards \\ Division \\ Office of Radiation Programs \\ Environmental Protection \\ Agency \\ Washington, DC 20460 \\ R. F. Overmyer \\ Ford Bacon and Davis \\ P.0. Box 8009 \\ Salt Lake City, UT 84108
}

D. Lewis

Jacobs Engineering Group, Inc.

Suite 1700

5301 Central Ave., NE

Albuquerque, NM 87108

K. R. Krishnan

Program Manager

Jacobs Engineering Group, Inc.

Suite 1700

5301 Central Ave., NE

Albuquerque, NM 87108

R. Peterson

Document Contro?

Jacobs Engineering Group, Inc.

Suite 1700

5301 Central Ave., NE

Albuquerque, NM 87108

T. N. Narasimhan

Earth Sciences Division Lawrence Berkeley Laboratory

Berkeley, CA 94720 
No. of

Copies

0. D. Markham

Radiological and Environmental

Sciences Laboratory

P.0. Box 2108

Idaho Falls, ID 83401

K. Bush

Research Institute for Geochemistry

2693 Commerce Road

Rapid City, SD 57701

10 K. K. Nielson

Rogers \& Associates Engineering

P.0. Box 330

Salt Lake City, UT 84110

10 V. C. Rogers

Rogers \& Associates Engineering P.O. Box 330

Salt Lake City, UT 84110

P. J. Rafferty

Roy F. Weston, Inc.

Weston Way

Westchester, PA 19380

G. Gnugnoli

Mail Station 1130-SS

U.S. Nuclear Regulatory

Commission

Washington, DC 20555

W. A. Nixon

Office of Nuclear Materials, Safety and Safeguards

Mail Station 296-SS

U.S. Nuclear Regulatory Commission

Washington, DC 20555

F. Swanberg

Mail Station 1120-SS

U.S. Nuclear Regulatory Commission

Washington, DC 20555
No. of

Copies

G. S. Campbe 11

Soils Department

Washington State University

Pullman, WA 99164

ONSITE

DDE Richland Dperations office

H. E. Ransom

5 Rockwell Hanford Operations

H. E. McGuire

S. J. Phillips

J. F. Relyea

J. Waugh

S. A. Weigman

United Nuclear Corporation

P. G. Ortiz

46 Pacific Northwest Laboratory

P. A. Beedlow

J. L. Buelt

J. F. Cline

M. E. Dodson

J. L. Downs-Berg

D. W. Dragnich

M. J. Fayer

M. G. Foley

H. D. Freeman

G. W. Gee (20)

M. J. Graham

J. N. Hartley

P. R. Heller

D. R. Kalkwarf

R. R. Kirkham

A. E. Reisenauer

J. V. Robinson

C. S. Siminons

J. A. Stottlemyre

$L$. L. Wendell

Publishing Coordination (2)

Technical Information (5) 
